\title{
On the Prothalli of Ophioglossum pendulum and Helminthostachys zeylanica.
}

BY

\author{
WILLIAM H. LANG, M.B., D.SC., \\ Lecturer in Botany at Queen Margaret College, Glasgow University.
}

With Plates I, II, and III.

\section{INTRODUCTION.}

THE difference of opinion which exists among investi1 gators who have studied the Ophioglossaceae, as to the phylogeny of this small group of Vascular Cryptogams, is well known. Palaeobotany has not afforded decisive indications of connecting links with either the Filicineous or the Lycopodineous phylum and comparative study of the existing forms is alone available in the solution of the problem. Thus the more extended and detailed our knowledge of all the stages of the life-history of the Ophioglossaceae becomes, the better will be the chance of discovering their relationship to other groups. In the present paper only the evidence afforded by the gametophyte is considered. The prothallus is already known in Ophioglossum pedunculosum ${ }^{1}$ and in Botrychium Lunaria $^{2}$ and $B$. virginianum ${ }^{3}$. Since the characters of these prothalli are described in the text-books, and will have to be considered in the general discussion below, no summary of

1 Mettenius, Filices Horti Botanici Lipsiensis. Leipzig, 1856, p. II 9, Pl. XXX.

${ }^{2}$ Hofmeister, Higher Cryptogamia. London, 1862, p. 307 , Pl. XLI.

${ }^{3}$ Campbell, Mosses and Ferns. London, 1895, p. 225. Jeffrey, The Gametophyte of Botrychium virginianum. Trans. Canadian Institute, $1896-7$, p. 265.

[Annals of Botany, Vol. XVI. No. LXI. March, 1902.] 


\section{Lang.-Prothalli of Ophioglossum pendulum}

the literature need be given here. The prothalli of Ophioglossum pendulum and Helminthostachys zeylanica ${ }^{1}$ will first be described, so that comparison can be made on the basis of a knowledge of this stage in all three existing genera. The material on which the investigation of these prothalli has been made was obtained from the Barrawa Reserve Forest at Hanwella in the Western Province of Ceylon. The prothallus of $O$. pendulum was collected on a visit to this locality in October, 1900: this was made in the company of Mr. F. Lewis, to whom I am indebted for great assistance in the search, and for the facts, regarding the peculiar conditions, which obtain in this low-lying forest. Those of Helminthostachys were collected in the beginning of the succeeding March, and the material which I obtained was supplemented by more than fifty prothalli obtained from the same locality by Mr. A. K. Coomara Swamy a few weeks later and kindly forwarded to me. I wish to express my thanks to $\mathrm{Mr}$. Coomara Swamy for generously placing this large stock of material at my disposal for the purpose of this investigation: without it certain facts would have been missed and others could not have been investigated so fully. The large number of prothalli under observation has also removed doubts as to the characters noted being normal. I have further to thank my friend Mr. Willis, the Director of the Peradeniya Botanic Gardens, for much assistance in selecting localities in which to search for these prothalli.

\section{OPHIOGLOSSUM PENDULUM.}

The sporophyte of this plant was frequently seen hanging from masses of epiphytic Ferns, its roots being embedded in the humus accumulated by the Ferns. It sometimes grows upon plants of Cycas or Phoenix, hanging from the stem below the crown of large leaves. A number of specimens, which grew on Asplenium nidus and Polypodium quercifolium, were carefully examined. In the humus collected by a mass of the latter Fern numerous prothalli were found. They were

${ }^{1}$ A preliminary statement on these prothalli has been published in the Proc. Roy. Soc., vol. lxviii, I90I, p. 405 . 
distributed throughout the humus but were most numerous close to the rhizome of the Polypodium, often being situated between its ramenta. The following account is based on the examination of this material.

The first stages in the germination of the spore of this plant have been described by Campbell ${ }^{1}$. After a year and a half the largest prothalli consisted of but three cells and were still partially enclosed in the exospore. Chlorophyll had not been developed in them.

The smallest prothalli found in nature, one of which is represented in Pl. I, Fig. I, are, as the side view shows, narrow below and widen out rapidly above. The gently convex upper surface is smooth, while the sides are covered with short unicellular hairs. The basal region is light brown, the upper part white. Regarding the colour of the prothalli it may be said generally that the younger regions are white, the older parts being more or less discoloured. Viewed from above or below, the outline of the prothallus of this age is circular, and a comparison of the different aspects shows that it is radially symmetrical. This radial symmetry is retained in all the branches of the older prothalli.

Sometimes the young prothallus continues its growth without branching, but as a rule branching occurs in prothalli which have reached the size of that just described. Usually two or three branches of equal size are developed (Figs. 2-4). These are connected by a region, which corresponds to the lower portion of the unbranched prothallus. The specimen in Fig. 2, in which the origin of two branches is visible, was attached to a fragment of tissue in the humus. That shown in Fig. 3 had evidently given rise to two branches, one of which has again branched. In Fig. 4 a prothallus with three branches is seen, and this is also the case in the older prothallus represented under a lower power in Fig. 5. The first branches, as these figures show, have a slight upward direction. In larger prothalli the primary branches have in turn branched, sometimes in a horizontal, at other times in a vertical plane,

1 Mosses and Ferns, p. 224. 


\section{Lang.-Prothalli of Ophioglossum pendulum}

and the old prothalli (Fig. 6) thus come to consist of short, stout branches radiating in all directions into the humus.

All the branches are similar in external form. The end of one is represented as seen from the side in Fig. 7. As this figure shows, the apical region is conical and its surface smooth. A short distance from the growing-point, however, the branch has attained its full thickness, and its surface has become covered with short wide hairs. Rhizoids appear to be entirely wanting. Both kinds of sexual organs occur on the same branch, but only the antheridia are conspicuous on external examination.

The general structure of a young prothallus is shown in longitudinal section in Fig. 8. The details of apical growth and of branching have not been followed in the few specimens of this age, but this omission is the less important, since there is no reason to expect any essential differences in this respect between the young prothallus and the branches of older ones. The tissue of the young prothallus is throughout parenchymatous: the cells of the lower half contain an endophytic Fungus, while those of the upper portion are free from it. At the extreme base, where presumably the spore membrane was attached, the surface is smooth and a few superficial cells contain the endophyte. A little above this the superficial layers become free from the Fungus, and throughout the further growth of the prothallus the endophyte is confined to internal tissue, the outer cells being only traversed by infecting hyphae. Many of the cells of the outermost layer give rise to short wide hairs, but these are absent at the extreme base and over the meristematic region. The breadth of the apical region in this specimen probably indicates that it was destined to give rise almost at once to several branches. Other specimens, while agreeing in general structure, have this region less flattened, and were probably about to continue their growth without for the time branching (Fig. 9).

A more detailed account must be given of the structure of a branch of the prothallus such as that described above (Fig. 7). The apical growth of such a branch can be referred to a single 
initial cell. In longitudinal section this is seen to be triangular in form (Fig. IO); in transverse section it is four-sided (Fig. II). The apical cell is thus a four-sided pyramid with a convex base, and segments are cut off in regular succession by walls parallel to the four sides. Each segment becomes subdivided by periclinal and anticlinal walls, the general direction of which will be evident from the figures. These first periclinal divisions do not appear to mark off definite structural regions, but a short distance behind the apex a superficial zone, in which the divisions are mostly parallel to the surface, can be distinguished from the central tissue of the branch. It is in this outer zone that the sexual organs originate, periclinal divisions in the cells between them keeping pace with their growth. Slightly further from the apex the tissues have become fully developed, but are still free from the endophytic Fungus. In this region the sexual organs become mature and open. On passing to the still older part of the branch, the Fungus is found occupying the internal tissue. These regions are shown in the longitudinal section through a branch (Fig. I2), which also shows the slight histological differentiation in the prothallus, due to the central cells being somewhat elongated. In transverse section (Fig. i3) these central cells are rounded, while towards the periphery of the section the cells are flattened parallel to the surface. The section represented in this figure passes through the region in which the endophyte is just making its appearance.

The short wide hairs (Fig. I4), the appearance of which in surface view has been seen, originate from single superficial cells of the branch a short distance behind the apex of the latter. Each cell giving rise to a hair projects as a conical papilla; the projecting part is then cut off by a periclinal wall. The hair remains unicellular ${ }^{1}$. Its nucleus, which is often suspended in the centre of the cell, may be round or be more or less elongated in the direction of the length of the

1 The abundance of these hairs in this epiphytic prothallus suggests a comparison with the multicellular paraphyses known in the prothalli of several species of Lycopodium and especially well developed in some epiphytic forms. 


\section{Lang.-Prothalli of Ophioglossum pendulum}

hair. Numerous colourless plastids are present in the cytoplasm around the nucleus. The outer cell-walls, whether of the hairs or of other superficial cells, possess a moderately thick cuticle.

To complete the description of the vegetative portion of the prothallus, the distribution and structure of the endophytic Fungus must be referred to. It has been seen that the Fungus in the young prothallus occupies the superficial cells at the base and extends into the central tissue of the lower half of the prothallus. This distribution is also recognizable in the old branched prothallus when the section passes through the central region, which corresponds to the base of the young prothallus. In the further growth of the prothallus, however, one or two superficial layers of cells always remain free from the endophyte, save for hyphae making their way into the deeper tissue. The diagram (Fig. I5) will make this clear. In the older region of a branch the Fungus occupies all the cells save the superficial zone of one or two layers. On passing towards the apex of the branch the Fungus may disappear from the central cells also, persisting however for a longer or shorter distance in an intermediate zone of tissue. In other cases the endophyte stops at the same level in both the axial and the more external cells.

Since the first stages of germination of the spore have not been followed information as to the first infection of the prothallus with the symbiotic Fungus is wanting. There is however a process of repeated infection, to which the extension of the Fungus towards the apex of the branch must in great part be ascribed. It will be convenient to trace the entrance of the Fungus at one of these points of infection and to consider the several structures in the order of their appearance.

When a branch is examined from the surface, coarse brown hyphae can be seen more or less closely applied to its surface. The filaments which penetrate the prothallus are in connexion with these, and as a rule enter by one of the hairs. That they are branches of the external mycelium entering at these points, and not branches of the endophytic mycelium 
making their way out to ramify in the soil, is clear from the relations of the hyphae at the points in question. Thus the entering filament is almost always given off at right angles from a hypha crossing the outside of a hair, and, when the first branching of the hypha within the prothallus is visible, it always suggests the subdivision of an entering hypha (Fig. I6). The penetrating hyphae, like those on the outside of the prothallus, are of considerable thickness. They are at first straight and run at right angles to the surface. Sometimes the hypha branches while in the hair, but more often this does not take place until it has penetrated to the hypodermal layer. In this there is often a considerable horizontal extension of branches from which vertical hyphae in turn originate. In the cells below the hypodermal layer other structures begin to make their appearance, these are small thin-walled vesicles (Fig. 17), the connexion of which in bunches borne on fine hyphae can now and then be traced. A number of these vesicles occur in each cell, often close to the nucleus. They are filled with protoplasm, in which a number of small nuclei are distributed. Other cells contain thick coiled hyphae, while in the older regions thick-walled, irregularly-shaped bodies of a brown colour are occasionally found. The mode of development and the function of these latter bodies is uncertain.

The general characters of the mycorhiza of the prothallus of Ophioglossum pendulum agree closely with those of the Fungus found by Janse ${ }^{1}$ in the roots of the plant. The starch-containing vesicles, mentioned by him, have however not been seen. Numerous plastids occur in the cells of the prothallus, and these, both towards the apex of the branch and in cells occupied by the Fungus, contain abundant starch.

The antheridium originates from a single superficial cell, the first division in which is parallel to the surface. The outer of the two cells thus separated gives rise to the onelayered wall: the inner undergoes numerous divisions and

1 Ann. Jard. Bot. Buitenzorg, xiv, Pl. IX, Figs. I I-I3. 


\section{Lang.-Prothalli of Ophioglossum pendulum}

produces the group of spermatocytes (Figs. I 8-20). The first divisions in the inner cell are as a rule anticlinal, followed by a periclinal division in each of the resulting segments.

The mature antheridia do not project from the surface of the prothallus and are only conspicuous on external examination by reason of the mass of spermatocytes, showing through the thin outer wall (Fig. 7). In vertical section (Fig. 2I) the large oval mass of spermatocytes, the greatest diameter of which is parallel to the long axis of the branch, is seen to be surrounded by a limiting layer of flattened cells. This layer and the one outside it are never invaded by the hyphae of the Fungus (Fig. 23). The true wall of the antheridium is of small extent, flat or very slightly convex. It is a single layer of cells thick ${ }^{1}$ and in surface view shows a triangular opercular cell (Fig. 22), which breaks down to give exit to the spermatozoids. The latter were unfortunately not examined when the material was collected, and it has not been found possible to ascertain their exact form or the number of cilia they possess from the study of those still in the antheridium.

The archegonium also arises from a single cell, which divides into three by two periclinal walls (P1. II. Fig. 24). The outermost of these gives rise to the neck, the middle to the central series, while the lowest of the three is the basal cell. The basal cell usually undergoes a few divisions, but its outline remains clearly recognizable in mature archegonia. The cell which gives rise to the neck divides by anticlinal walls into four ; each of these gives origin to one of the four rows of cells (Fig. 27) of which the neck consists. There are as a rule four cells in each row, but sometimes only three. The neck hardly projects above the general surface (Fig. 25). The central cell early divides into two, the upper of which insinuating itself between the neck-cells is the neck-canal-cell (Fig. 25). This becomes binucleate (Fig. 26), but no cell-division has been observed to follow, nor has the division of the middle

\footnotetext{
1 Exceptionally the cells of the wall undergo a periclinal division in old antheridia.
} 
cell into ovum and ventral canal-cell been observed, though analogy suggests that it will be found to take place.

The segmentation of the ovum has also not been traced, but embryos were present on a few of the prothalli. They were all of about the same age and presented the appearance represented in Fig. 28, the embryo being conspicuous as a globular projection from the side of a branch of the prothallus. Up to this stage the embryo is completely enclosed by the tissues of the gametophyte and surmounted by the brown archegonial neck. These embryos were rather old to do more than indicate the order of segmentation, and too young to make the delimitation of the primary members of the young plant certain. A median vertical section (Fig. 29) shows the main structural features most clearly. The whole of the lower portion is evidently to be regarded as foot; the smaller upper portion consisted of cells with more abundant contents, but the position of the primary organs could not be determined in it. The first wall separating these epibasal and hypobasal halves can be clearly traced and, as a series of transverse sections through another embryo showed, the quadrant and octant walls followed in each of these halves. The resemblance of these embryos to one stage of the embryo of Botrychium virginianum, which will be evident on comparing Fig. 29 with Fig. 46 of Jeffrey's paper on the latter plant, makes it probable that the earlier and later stages will also be found similar in the two genera.

\section{HELMINTHOSTACHYS ZEYLANICA.}

The prothallus of Helminthostachys was looked for in a number of localities in Ceylon and the Malay Peninsula. The sporophyte is found growing under very various conditions in its different habitats. In native compounds under Coco-nut palms it grows in rather dry soil, owing its success and its spread, so far as could be seen, to its power of continued growth and to vegetative multiplication. The same conditions appear to obtain in the Botanic Gardens at 


\section{Lang.-Prothalli of Ophioglossum pendulum}

Heneratgoda, and here also the fronds appear among the grasses covering the soil. In other localities isolated plants were found close to streams growing in the mud. At Hanwella the plant grows commonly in the dry compounds, but is also abundant in a small Teak plantation and in Barrawa Reserve Forest. In both these situations the soil is covered with dead leaves and the undergrowth is scanty. The reserved forest of Barrawa is situated on the Puselli Oya, a branch of the Kelani river, and is about eighteen miles from Colombo. It stands about forty feet above sea-level and is very frequently flooded. These floods depend on the abundance of the rainfall round the head waters of the Kelani river which drains one of the wettest districts in Ceylon, and not directly on the rainfall of Barrawa. The flood covers the land with water to a depth of fifteen to twenty feet, and, as the outflow is not swift, lasts for several days at a time. In October, I900, when this locality was first visited, the forest was in flood and no Helminthostachys was found. On revisiting the forest in the following March the floor of the jungle was dry and was found to be composed of fallen leaves mixed with fine-grained mud. In the lowlying parts there were very few undergrowth plants, Helminthostachys being the most abundant. In the spots where the mature plants grew, young plants could be recognized by the small ternate lamina which appears above the surface. These were still attached to the prothallus and, by searching in the leaf-mould around, a few free prothalli were obtained. The following description is based on the material thus collected, supplemented by the prothalli obtained by Mr. Coomara Swamy, on a subsequent visit to the same locality, which he generously put at my disposal.

\section{The Prothallus.}

The prothalli are subterranean and occur at a depth of about two inches. In colour they are brown, the apex and younger parts being white. Their position in the soil is variable, but most commonly the long axis is vertical, the 
apex being directed upwards. Prothalli of different sizes were found, but the earlier stages of development were not seen. The smallest prothallus obtained is represented in Fig. $3^{\circ}$. Fig. $3^{1}$ represents a rather larger prothallus, which was however capable of further growth, while that in Fig. $3^{\circ}$ has almost attained its full size. Both of them show a more or less swollen lower region, which bears rhizoids and is of a brown colour. From this a cylindrical growth has arisen, at the apex of which the growing-point is to be found, the antheridia arising in acropetal succession behind the latter. The distinction into a lower portion bearing rhizoids and an upper on which the sexual organs are situated is most clearly seen in Fig. 3 I. It can be traced in all the prothalli, and since the endophytic Fungus is contained in the lower portion this will be spoken of as the vegetative region, and the longer or shorter cylindrical upper part as the sexual region.

The relative development of the vegetative and sexual regions, and consequently the general form of the prothallus, differs according to whether the prothallus bears antheridia or archegonia. There is in fact an imperfect sexual differentiation analogous to that known in the gametophyte of some other homosporous Vascular Cryptogams. Certain prothalli produce antheridia only; others, after a few antheridia have been produced, bear archegonia. The fact that the female prothalli nearly always bear a few antheridia first, makes it probable that, up to a stage like that represented in Fig. $3^{1}$, there would be little or no difference between the two forms.

Three male prothalli are represented in Figs. 32-34. In them the vegetative region is relatively small. It is slightly lobed in the prothallus represented in Fig. 32, more strongly in the other two. This lobing of the basal region is not a true branching, but results from unequal growth of the originally unlobed basal region. A true branching, referable to the growing-point, has in no instance been observed, and may safely be regarded as exceptional. The sexual region is cylindrical, of fairly uniform thickness, and attains a con. 


\section{Lang.-Prothalli of Ophioglossum pendulum}

siderable length. Its lower portion bears spent antheridia, while towards the apex mature and young antheridia are found.

The prothallus represented in Fig. 35 is of interest, since it presents characters intermediate between those of the typical male and female prothalli. Its vegetative region is larger and more strongly lobed than in the male prothalli, while the sexual region, though shorter and thicker than in the latter, is of considerable length. A number of antheridia are present on its lower part, while above these archegonia have formed. The more ordinary type of female prothallus is illustrated by Figs. 36 and 37 . In these the lobed vegetative region forms the greater part of the prothallus, the sexual region being very short and wide : both these prothalli bore embryos.

The general structure of the prothalli will be evident from the diagrams (Figs. $3^{8-40}$ ), which represent in longitudinal section one of the youngest prothalli, a full-grown male and a female prothallus respectively. In all the diagrams the region occupied by the endophytic Fungus is shaded, and the position of the sexual organs is indicated ; these characterize the vegetative and sexual regions, which have already been distinguished in considering the external morphology. In the young prothallus (Fig. $3^{8}$ ) the sexual region is still relatively small, only a few antheridia ( $a n$.) having been produced behind the apex $(a$.). The beginning of the formation of lobes of the vegetative region is seen at l.l. The further growth of the older male prothallus (Fig. 39) is seen to have been mainly due to the increase in length of the sexual region, the vegetative region having in this case become only slightly lobed. In the female prothallus (Fig. 40), on the other hand, the region containing the endophyte is large and strongly lobed, while that bearing the archegonia (ar.) is short; owing to the presence of a fairly large embryo on this prothallus the apex could not be distinguished. A few antheridia are present behind the archegonia ; they are indeed in such cases often situated on the region containing the Fungus. All the diagrams 
indicate the freedom of the superficial layers of the vegetative region from the Fungus.

Owing to the growth in length and formation of new sexual organs having ceased in almost all the available prothalli, the apex was somewhat difficult to investigate. It was however determined that growth was referable to a single apical cell; in longitudinal section this appears triangular (Fig. 4I), in cross section or in apical view it is four-sided. Thus, as was the case in Ophioglossum pendulum, the apical cell is here a four-sided pyramid. The segments, which are cut off by walls successively parallel to the four sides, soon divide by periclinal walls; the inner cells contribute to the axial tissue, while the layer in which the sexual organs are formed can be traced to the superficial segments.

The structure of the sexual region is most clearly shown in the male prothalli. Fig. 42 represents a median longitudinal section through this region, and Fig. 43 a transverse section. The uniform distribution of the antheridia round the circumference of the latter section makes the radial symmetry of the prothallus evident. The tissue between the antheridia shows indications of having arisen by periclinal divisions of superficial cells keeping pace with the increase in size of the antheridia. The central tissue consists of elongated cells, which are polygonal in cross section. They have thin transverse septa. The appearance of this tissue suggests that it is useful in the conduction of plastic material from the vegetative region to the growing-point. The structure of the short wide sexual region in the female prothallus is essentially similar, but the elongation of the central cells is less marked.

The outer two or three layers of cells of the vegetative region (Fig. 44) are somewhat flattened. Here and there cells have grown out into rhizoids, the bases of which alone remain in the specimen figured. An uninjured rhizoid is shown in Fig. 46 ; it is unicellular, and is separated from the underlying cell by a wall parallel to the surface of the prothallus. A cuticle, staining yellow with Schultze's solution, is present on the rhizoids and extends continuously over the surface of 


\section{Lang.-Prothalli of Ophioglossum pendulum}

the prothallus; all the other walls stain blue with this reagent. The tissue containing the endophyte comes within these superficial layers. It is composed of parenchymatous cells, no marked elongation being recognizable even in the axial region. The cells containing the Fungus are mixed in about equal numbers with others similar in size and shape, which contain numerous starch-grains (Fig. 45). Starch is also to be found in cells containing the Fungus.

It has already been mentioned that the appearance of the lobes of the vegetative region does not suggest their origin as branches referable to the apical growth. Fig. 45, which is a section through a young lobe of the prothallus shown in Fig. 38 , indicates that the lobe arises by divisions taking place in a considerable number of cells of the outer layers. The tissue resulting from this generalized meristematic activity is at first free from the Fungus; subsequently the latter extends to the central tissue of the lobe, which then presents the same appearance in section as the unlobed vegetative region (Fig. 44).

The distribution of the endophytic Fungus has been indicated above. It remains to consider its structure and the changes it undergoes during the growth of the prothallus. In nearly every rhizoid, hyphae were seen, which presumably enter from the soil. In the older prothalli the rhizoids often break down, exposing the hyphae (Figs. 46, 47). The hyphae run down within the rhizoid and enter the underlying cell, across the cavity of which they usually pursue a straight course. In the outer two or three layers the filaments may branch and sometimes run for a short distance parallel to the surface, but they do not give rise to other organs as in the deeper tissues. In the cells of the latter, when sections through a young prothallus are examined, large oval or spherical vesicles with thin walls are found (Fig. 48). These may occur singly or several together, and vary in size. Occasionally their connexion with the fine hyphae entering the cells can be observed. The vesicles have a protoplasmic body, which, in some cases, completely fills them ; in most it forms 
a thicker or thinner lining to the wall. Small nuclei are present in the protoplasm either distributed or aggregated together. The cells, in which these structures lie, are healthy; starch is as a rule, though not always, absent from them. It is abundantly present in the adjoining cells, from which the Fungus is absent (Fig. 48), and in smaller grains in those of the superficial layers.

In prothalli, only slightly larger than the one on which the above description is based, a remarkable change has come over the whole of the endophytic Fungus. Instead of healthy hyphae and vesicles there is found in each of the funguscontaining cells a number of small shrivelled bodies, which can sometimes be seen to be attached together by fine hyphae (Fig. 49). It is thus clear that the existence of the endophyte is arrested long before the growth of the prothallus is completed. The materials for this are present in the form of starch, the distribution of which has been noted above. The starch can be traced up to the apex, but is absent from the peripheral tissue between the mature and old antheridia. By comparing older male prothalli the gradual withdrawal and utilization of this reserve starch can be followed, the last traces of it being detected in the cells close to the apex. With this last condition the arrest of growth of the sexual region is correlated, and in such prothalli mature or emptied antheridia are present close to the apex, instead of the young ones which occupy this position in prothalli capable of further growth.

It would thus appear that the relation between the prothallus and the mycorhizal Fungus is somewhat peculiar in Helminthostachys, in the sharp distinction between a stage, in which organic substance is manufactured, and one in which it is utilized. During the former stage the Fungus is healthy, but the growth of the sexual region has barely commenced before the Fungus dies; the further growth of the sexual region takes place at the expense of, and up to the limit permitted by, the amount of the reserve material. There is thus a definite limit to the full size of each male prothallus; but 


\section{Lang.-Prothalli of Ophioglossum pendulum}

since the amount of reserve material is different in different individuals, a corresponding variation in size is found. That size is no safe guide to the age of the prothallus a comparison of Figs. 30 and 34, which represent prothalli on the eve of arrest of growth owing to the exhaustion of their reserve food, clearly shows.

In the above account the nutrition of this prothallus has been regarded chiefly as shown in the male individuals. An equally full series of the female prothalli was not available, and in all examined the Fungus was in the shrivelled, dead condition described above. In prothalli such as those in Figs. $3^{6}$ and 37 , in which the young plant is just becoming visible, nearly all the cells of the large, lobed, vegetative region are packed with starch-grains. The cessation of growth does not here depend on the exhaustion of the food material, but on the fertilization of an archegonium and the subsequent changes. Judging from a large number of female prothalli attached to young plants, fertilization usually occurs when only a short sexual region bearing archegonia has formed. The large amount of reserve material remaining is here available for the nourishment of the embryo and young plant ; its exhaustion is not complete, though nearly so, when the first leaf of the latter is expanded and exposed to the light.

The position of the sexual organs has been indicated above. It remains to describe their structure and development. The antheridium is referable to a single superficial cell, the first division in which is periclinal, and separates the wall from the cell which forms the spermatozoids. Figs. 50-52 (Pl. III) are from median sections of developing antheridia, and Fig. 52 should be compared with Fig. $53 a, b$, which represent two horizontal sections through an antheridium of corresponding age. A certain regularity exists in the earlier divisions in both the outer and inner cells. The former is first divided into four by anticlinal walls; the latter becomes divided by successive walls into octants and, by further divisions, is converted into the mass of small spermatocytes.

The mature antheridium presents some peculiarities. Like 
those of the other Ophioglossaceae, it projectsvery slightly from the general surface. The large oval mass of spermatocytes is surrounded by a layer of flattened cells, derived from the cells around that which gave origin to the antheridium. The true wall of the antheridium, derived from the outer segment of the mother-cell, is, however, different in some respects from that of any other known antheridium. It is shown in section in Figs. 54 and 56, and in surface view in Fig. 55. For the greater part of its extent it is two-layered, a periclinal division having taken place in most of the cells, into which it had divided by anticlinal walls. A few cells, however, remain undivided, so that at these spots the wall is one-layered. These single cells are large and prominent both in section and surface view, and also stand out in contrast to the others by reason of their more deeply staining contents. It is by the breaking down of one of these cells that the dehiscence of the antheridium takes place. Rarely a single dehiscence-cell is found in a nearly central position; usually two, three, or four exist, situated close to the periphery of the antheridial wall. When old antheridia are looked at from the surface, all these cells appear darker brown, but only one is found to have broken down to give exit to the spermatozoids. The latter were unfortunately not examined alive, and, as in the case of Ophioglossum pendulum, the examination of those in the antheridium has only shown a general agreement in form with those of other Ophioglossaceae : it was not found possible to determine the number of cilia.

All the female prothalli which were found had young plants or, in the case of two or three, large embryos. A satisfactory study of the archegonium was thus impossible, and the following description is based on the unfertilized archegonia borne on the prothalli with the youngest embryos. As fertilization appears in all cases to arrest the growth of the prothallus, the development of the archegonium could not be followed. Fig. 57 represents an archegonium in median section. The neck projects considerably from the surface of the prothallus : the projecting portion consists of four rows 


\section{Lang.-Prothalli of Ophioglossum pendulum}

(Fig. $5^{8}$ ) of cells, each row consisting of about six cells, somewhat flattened parallel to the surface. The cells of the neck turn dark brown in old archegonia. The central series could only be imperfectly made out : there is a large ovum, but the number of canal-cells could not be determined. From the arrangement of the cells at the base of the ovum, it seems probable that a basal cell will be distinguishable in the developing archegonium. The possibility of some slight distortion due to the growth of surrounding cells must of course be borne in mind in considering the structure of such old archegonia, but was probably inconsiderable in the example figured.

A number of archegonia had apparently been simultaneously fertilized on a few of the prothalli which were attached to young plants. The preservation of the arrested embryos, which were present in addition to the plant, was not good enough to make a study of the segmentation possible. It was however clear that, as in Botrychium, the young embryo soon becomes deeply seated. The larger embryos present on the prothalli represented in Figs. 35-37 were all about the same age. One of them is represented in approximately median section in Fig. 59. The large hemispherical foot is deeply inserted in the tissue of the prothallus. The upper portion of the embryo had burst through the covering layers of the latter; in it can be distinguished the primary root $(r)$, the median plane of which fell in another section of the series; the first leaf $(l)$, the tip of which is injured, and, (covered over by the sheath of the first leaf), the depressed apex of the stem (st.). The position of the organs of the embryo is thus essentially similar to what is found in Botrychium virginianum. The apical region of the stem of the embryo of Helminthostachys is shown in Fig. 60. At the base of the depression filled with hairs the initial cell is visible, and segments can be seen to have been cut off parallel to the sides and the truncated base. 


\section{Morphology and Anatomy of the young Sporophyte ${ }^{1}$.}

Two young plants still attached to prothalli are represented in Figs. 61 and 62. In the former the first leaf has fully expanded, and is seen to have a ternate lamina borne on a long, slender leaf-stalk. Close to the insertion of the primary root the foot is enclosed in the prothallus. An internode of some length occurs below the separation of the first leaf, and just above this the second root $(r)$ has emerged. The second leaf is about to break through the sheath of the primary leaf.

The plant shown in Fig. 62 is older, the second leaf having expanded, while the third root, which corresponds to the leaf still enclosed in the bud, has commenced to elongate. The oldest plant found attached to a prothallus bore three expanded leaves. All the young plants were dorsiventral even in the first internodes, which are usually vertical: the leaves are given off from one side of the axis and the roots from the other. Farmer and Freeman have recently shown that no definite relation exists between leaf and root in the older plants. In the young plant there is a correspondence in number between these organs, the primary root corresponding to the primary leaf, and a root arising from the stem just below each succeeding leaf-trace. The root attains a considerable length before the leaf, below which it arises, commences to grow. Even in the young plant, however, it arises from the stemstele, and not from the leaf-trace. The constant relation, which for a time exists between the leaf and root, while doubtless important physiologically, does not appear to possess any great morphological importance.

The structure of the mature plant of Helminthostachys has recently been fully investigated by Farmer and Freeman ${ }^{2}$, so that the observations made on the plants attached to prothalli need only be briefly described. This will supplement

\footnotetext{
${ }^{1}$ I am indebted to Mr. Gwynne-Vaughan for assistance and advice in the study of the young plants.

${ }^{2}$ Annals of Botany, vol, xiii, p. 42 I.
} 


\section{Lang.-Prothalli of Ophioglossum pendulum}

the account of the mature plant, and show in what particulars differences exist between them.

The general plan of construction of the roots of the young plant is similar to that of those springing from old rhizomes. As in these, root-hairs are absent, the outer walls of the superficial cells being at most bulged outwards to form short papillae. There is a broad parenchymatous cortex, in a middle zone of which an endophytic Fungus is present in the first two or three roots (Fig. 63). This appears to constitute a mycorhiza, as is the case with all the roots in some other Ophioglossaceae. The stele is surrounded by an endodermis with corky radial walls; within this comes a single layer of pericycle. The stele of the first root (Fig. 64) is constantly triarch. The three groups of xylem, with which the small phloëm-groups alternate, usually surround a small pith, though they are sometimes joined together. The second root is similar, but the stele is tetrarch (Fig. 63). The same holds for succeeding roots which show a gradual increase in thickness; the fourth root had its cortex free from Fungus and densely filled with starch, like the roots of the mature plant.

The internode below the first leaf varies in length and thickness in different individuals. The single stele also presents slight differences, though the general plan of construction is constant. It is limited on the outside (Figs. 65, 66) by a well-characterized endodermis, within which come one or two layers of fairly large clear cells, constituting the pericycle. The phloëm, which consists of narrow elements, surrounds the xylem. The xylem is in some cases a solid central strand, but more usually a few parenchymatous cells are present in it. These are often conspicuous in the centre, constituting a more or less distinct pith (Figs. 64,65). Just below the origin of the first leaf-trace the pith, if present, increases in size, and is continuous with the parenchyma intervening between the xylem of the departing leaf-trace and that of the stele. If the stele is solid in the lower part of the internode parenchyma appears in the centre of the xylem in preparation for the departure of the trace. As a rule the stele after. a leaf-trace 
has been given off is at first solid (Fig. 67), though centrally situated parenchyma usually reappears at a slightly higher level.

It depends on the individual plant how soon the stele begins to have a larger pith and approximate to the structure described and figured by Farmer and Freeman. The simple type just described may persist for a number of internodes. The material did not afford stages old enough to allow of the transition to the condition of things in the old rhizome being followed. The most advanced stage found was closely similar to the simplest stele described by Farmer and Freeman ${ }^{1}$. At this stage the stele as a whole was larger than that in Fig. 65 ; the pith consisted of a considerable number of cells as seen in cross section, though tracheides were distributed through it. No internal endodermis was present and the departing leaftrace did not even at this stage leave a leaf-gap, the ring of xylem closing up immediately.

In the solid steles and in those with a small pith the protoxylem is at, or nearest to, the centre and the development of the xylem is centrifugal. The elements of the protoxylem are spiral while the later formed tracheides are pitted. This endarch position of the protoxylem persists for several internodes in most cases (Fig. 70). Whether in the cases, in which tracheides were distributed through the pith, the protoxylem was mesarch or endarch could not be determined.

The origin of the first leaf-trace, with which succeeding traces originating from the more or less solid stele agree, is represented in Figs. 67 and 68 . At the level at which the sections figured are taken the endodermis is still complete, and encloses the stele together with the leaf-trace. At a slightly higher level it ceases to be continuous and immediately closes around the stele; it remains visible for some distance on the outside of the trace, and near the base of the latter forms a separate and complete sheath. The common type of leaftrace is that shown in Fig. 67, which is throughout endarch. In one or two cases even the first trace was at its origin and

\footnotetext{
${ }^{1}$ Farmer and Freeman, loc. cit., Fig. 23.
} 


\section{Lang.-Prothalli of Ophioglossum pendulum}

for the greater part of its course through the cortex somewhat different (Fig. 68). The difference consisted in the presence on the adaxial face of the bundle, separated from the protoxylem by some parenchymatous cells, of a few larger tracheides; the trace was thus mesarch. This agrees with what is found in the mature plant and suggests that the stele was in these cases probably mesarch also. The trace passes obliquely through the cortex, and may either enter the leafstalk as a single bundle or before doing so have divided into two bundles which face inwards and slightly towards one another (Fig. 69). No further divisions occur in the petiole ${ }^{1}$.

In most cases, even in relation to the first leaf, the slit-like organ, described for the older rhizome by Mr. GwynneVaughan in the present number of this Journal, could be traced down to the stele in front of the leaf. In the examples it was possible to study fully a similar disturbance of the endodermis to that described for the older plant was found in relation to this organ where it approaches the stele.

It is unfortunate that a complete series of stages between the solid monostele of the young plant and the stele of the mature plant with an internal endodermis was not available. The facts mentioned in the above description with regard to the variations in the size of the pith in the seedlings suggest that the transition is a gradual one, taking place by the increase in size of the pith, its limitation from the xylem by an indefinite endodermis and the appearance of definite leafgaps. The study of the young plant thus supports the view, expressed by Farmer and Freeman, that the occurrence of the internal endodermis in this plant is secondary and is connected with the appearance of leaf-gaps.

\section{SUMMARY.}

Ophioglossum pendulum.

I. The prothallus is a colourless saprophyte ; it is usually branched, the short branches radiating in all directions into

1 Sometimes an intercellular space arises by the breaking down of cells on the adaxial face of the bundles in the leaf-stalk, but this is not a constant feature. 
the surrounding humus. The growth of the young prothallus and of the branches is apical, a four-sided initial being present. Rhizoids are absent, but the surface is covered with short unicellular hairs.

2. A symbiotic Fungus is present in the internal cells of the prothallus. Repeated infection takes place through the unicellular hairs.

3. The prothallus is monoecious, the sexual organs arising in acropetal succession.

4. The antheridium originates from a single superficial cell. The mature antheridium is sunken; its outer wall is one layer of cells thick; the oval mass of spermatozoids is surrounded by a layer of flattened cells free from the endophyte.

5. The archegonium is developed from a single superficial cell. Its neck, which consists of four rows of cells, hardly projects from the surface. The ovum and a binucleate canal cell can be distinguished in the central series. A basal cell is present.

6. The embryogeny could not be completely studied ; the stage found showed a general agreement with other Ophioglossaceous embryos. Young plants were not seen.

\section{Helminthostachys.}

I. The prothalli are subterranean and wholly saprophytic ; they consist of a lobed basal portion (vegetative region), from which a cylindrical process (the sexual region) arises: the growth is apical, by means of a single initial cell. Rhizoids are present on the vegetative region.

2. A symbiotic Fungus is present in the cells of the vegetative region; it dies about the time that the sexual region begins to elongate, and growth is completed at the expense of the accumulated starch.

3. There is an imperfect sexual differentiation; the vegetative region is larger and more strongly lobed, and the sexual region shorter and thicker in the female prothalli, than in those which bear antheridia.

4. The antheridia, which originate from single superficial cells, are sunken. Their wall is in part two-layered, but the 
dehiscence-cells, of which several are present, do not undergo the periclinal division; only one of these cells breaks down on the opening of the antheridium.

5. The structure of the archegonia, which have long necks, like those of Botrychium, was not satisfactorily determined.

6. The old embryo resembles that of Botrychium; it has a large foot; the primary root, first leaf, and the stem-apex seem referable to the epibasal half.

7. The young plant remains attached to the prothallus until several leaves are formed. The first leaf has a ternate lamina and reaches the light. For a time a single root is developed below each leaf.

8. The first root is triarch, succeeding ones tetrarch. A mycorhizal Fungus is present in a medio-cortical zone of the first few roots.

9. The stele of the stem is at first endarch and may be solid or have a small pith; it is surrounded by a well-marked endodermis. The first leaf-traces are endarch or mesarch and do not leave definite leaf-gaps.

Io. Gwynne-Vaughan's organ is present even in relation to the first leaf.

\section{COMPARATIVE REMARKS.}

Although for the sake of completeness the anatomy of the young plant of Helminthostachys has been included in the preceding description, the following discussion will have reference only to the evidence as to the affinity of the Ophioglossaceae afforded by the gametophyte. The relative independence of the two generations in the Pteridophyta appears to justify such a separate consideration. The embryogeny may, however, be conveniently considered along with the prothallus, since the structure and mode of life of the latter are important factors in the environment of the embryo.

The prothalli of the three living genera of Ophioglossaceae, while differing in details, present essential points of agreement with one another. They are all wholly saprophytic and live 
beneath the surface of the soil or humus. They are normally devoid of chlorophyll, but this was developed when the prothallus of $O$. pedunculosum reached the surface and was exposed to light. In all the cases, in which its presence has been looked for, a symbiotic Fungus has been found in the tissues. Besides this physiological agreement, which might of course be due to independent adaptation, there are common characters in the general symmetry, the structure of the sexual organs and the embryogeny, to which a higher degree of morphological weight attaches. In all, the growth is localized in an apical meristem, behind which the new organs arise in acropetal succession. In Ophioglossum and Helminthostachys the general form is that of a rather stout cylinder, which may be more or less branched; in the distribution of its organs this exhibits strict radial symmetry. In both Botrychium Lunaria and $B$. virginiamum, however, a tendency towards a thick-flattened form can be recognized; this is less marked in the forms in which the sexual organs occur on all sides of the prothallus. In B. virginiamum they are definitely localized on the upper surface, the antheridia occupying a median ridge, while the archegonia are found on the flanks. Whether the flattened form of prothallus in Botrychium was derived directly from the unknown autophytic ancestry of the Ophioglossaceae, or has arisen by modification of the cylindrical type, an adaptive significance may be recognized in it. For the position of the sexual organs on the upper side of a flattened subterranean prothallus would be of advantage in arresting the water percolating downwards through the soil and allowing it time to bathe the sexual organs and permit of fertilization. Support is lent to the idea of some such view by the flattening of some of the subterranean types of Lycopodium prothalli, which, on this view, would be regarded as presenting an analogous but independent adaptation.

The sexual organs are also constructed on the same type throughout the Ophioglossaceae. The antheridia are large and sunken; the outer wall may be one-layered and dehiscence take place by the breaking down of a triangular opercular cell 


\section{Lang.-Prothalli of Ophioglossum pendulum}

(O.pendulum), but in all the genera a tendency to the doubling of the outer wall by periclinal division exists. This occurs exceptionally in $O$. pendulum, normally and in all the cells in O. pedunculosum and Botrychium, while in Helminthostachys several cells, through one of which dehiscence occurs, remain undivided. It may be assumed with probability that the onelayered wall represents the primitive condition, from which the other modifications have been derived. So far as is known (O.pedunculosum, Botrychium) the spermatozoids are multiciliate. The archegonia have a rather deeply sunken venter and a neck of four rows of cells which may hardly project from the surface (Ophioglossum), or be longer and project considerably (Botrychium, Helminthostachys). A basal cell has been found in all in which its presence has been looked for. The most extensive central series seen consistęd of the ovum, a ventral canal-cell, and a bi-nucleate neck-canalcell (B. virginianum).

The embryogeny is not completely known in all three genera, but the advanced stages of Ophioglossum and Helminthostachys show essential agreement with Botrychium, in which the segmentation is known in detail. No suspensor is formed. The whole of the hypobasal half forms the large hemispherical foot, while the first root, first leaf and stem-apex become distinguishable rather late in the epibasal half. The apex of the stem comes to occupy a depression in front of the first leaf.

Having thus reviewed the common characters of external form, reproductive organs and embryogeny in the Ophioglossaceae, the question arises whether a similar assemblage of characters is to be found in any of the three existing phyla of Vascular Cryptogams. There is little to suggest a close relationship between the Ophioglossaceae and the Equisetales, and the former group has usually been compared with the Lycopodiales or the Filicales ${ }^{1}$. In such comparisons it is

${ }_{1}^{1}$ Without summarizing the views expressed by these authors the discussions of the evidences of affinity afforded by the Ophioglossaceous prothallus by Bower (Studies II, Ophioglossaceae, London, 1896, p. 62), Jeffrey (loc. cit.) and Goebel (Organographie, p. 410) may be referred to. 
important to determine as far as possible the relatively primitive and the highly modified forms of prothallus in each group, and to confine the comparison mainly to the former. The heterosporous forms will therefore be left out of account here and only mentioned when they seem to weaken the evidence afforded by the homosporous forms.

The Lycopodiales may be taken first, since in this group prothalli, which are practically autophytic, and subterranean holosaprophytic forms occur: this makes it possible to ascertain the characters which remain constant in spite of this profound physiological change. In a previous paper ${ }^{1}$ reasons have been given for regarding the Lycopodium cernuum type of prothallus as the relatively primitive one in this group. The recently discovered prothallus of Phylloglossum ${ }^{2}$ gives further support to this view. In these prothalli an outstanding feature of the general plan of construction is the intercalary position of the meristem : from this additions are made to the vegetative region below, while the sexual organs originate above the meristematic zone, the youngest being found nearest to it. This special type of radial symmetry is retained in many of the subterranean forms, so that it is not necessarily obscured or lost in relation to such a change in the economy. Now the radial symmetry of the Ophioglossaceous prothalli, and the apical position of the meristem in them, stand in marked contrast to this and afford no suggestion of a common origin. Comparison is however at first sight more justifiable between the Ophioglossaceous prothalli and those of Lycopodium Phlegmaria. The fine cylindrical branches of the latter have apical growth, though, when sexual organs are formed, they originate on the upper side above the meristem. In the paper cited above reasons have been given for regarding this type of Lycopodium prothallus as derived from the type with an intercalary meristematic zone by limitation of growth

${ }^{1}$ Lang, Prothallus of Lycopodium clavatum. Annals of Botany, vol. xiii, I899, p. 279.

2 Thomas, Preliminary Account of the Prothallium of Phylloglossum. Prac. Roy. Soc., 1902. 


\section{Lang.-Prothalli of Ophioglossum pendulum}

to special points in the latter; the various forms of $L$. Selago prothallus indicate how this may have come about. If this interpretation, on which the L. Phlegmaria type would be regarded as a highly specialized one, is correct, little weight can be attached to the resemblance between it and the prothallus of Ophioglossum; the resemblance is further not a very close one.

Important points of difference are also found when the sexual organs of the Ophioglossaceae and the Lycopodiaceae are compared. The general construction of the antheridia is indeed not dissimilar, but, since the plan of these organs is alike in all the eusporangiate Vascular Cryptogams, no weight can be attached to this. A point of difference is found in the spermatozoids, which are multiciliate in the Ophioglossaceae, biciliate in the Lycopodiales ${ }^{1}$. The archegonia in both groups exhibit a series from short-necked to long-necked forms. Their development affords a constant difference in the presence of a basal cell in the Ophioglossaceae and its absence in the Lycopodiales. The presence of a suspensor in the embryo of the latter group, and the origin of the primary leaf and root and the apex of the stem from the end furthest from the suspensor, are important points of difference.

To sum up the comparison between the Ophioglossaceae and the Lycopodiales, it does not appear too much to say that, while some general resemblances standing in relation to similar modes of life can be traced, there are no characters, the morphological value of which is attested by constancy throughout obviously allied groups, indicating affinity between the two. On the other hand, important points of difference exist in type of symmetry, in the sexual organs, and in the embryogeny.

The Ophioglossaceae are usually included in the Filicales, and a similar comparison must now be made with this phylum

1 The isolated heterosporous genus Isoetes has multiciliate spermatozoids, and also differs from the other Lycopodiales in the absence of a suspensor. Without attempting to estimate the weight to be attached to these exceptions, it may be pointed out that their existence does not seriously affect the above comparison of the prothalli of the homosporous Lycopodiales and the Ophioglossaceae. 
to ascertain whether the evidence from the gametophyte renders this view probable or not. The eusporangiate Marattiaceae must be specially considered, but the general similarity in all the homosporous Filicales justifies the use of evidence from the leptosporangiate forms also. In considering the general symmetry the difficulty presents itself that no holosaprophytic fern-prothalli are known. In the flat green prothalli the meristem is apical and the succession of the sexual organs acropetal. The latter are developed on the under surface of the dorsiventral prothallus, but this distribution is well known to be due to an irritability to light. When, under cultivation or in nature, this and possibly other stimuli act more uniformly on all sides of the prothallus, the flattened form is lost and the prothallus may continue its growth as a cylindrical process with an apical meristem ${ }^{1}$. This growth-form presents points of resemblance with the prothalli of Ophioglossum and Helminthostachys in its symmetry, its apical growth, and the uniform distribution of the sexual organs on its surface. Something similar is seen in Gymnogramme leptophylla ${ }^{2}$, in which the process which bears the archegonia buries itself in the soil ; this was early compared by Goebel to the Ophioglossaceous prothallus, though his suggestion that a preliminary green stage might occur in them also has not been borne out. These modifications of the common flat prothallus in the Filicales suggest that, were it possible to cultivate them below the surface of the ground, the form of a cylindrical structure with apical growth would probably be maintained throughout life. As regards form and symmetry the type of prothallus which might be expected to result is realized in the Ophioglossaceae, and it will be remembered that when the cylindrical process of $O$. pedunculosum reached the light it became flattened and lobed.

The structure of the sexual organs affords support to such an origin of the Ophioglossaceous gametophyte from

${ }^{1}$ Cf. Lang, On Apogamy, \&c. Phil. Trans., 1898, Ser. B, p. 187, Pl. VII, Figs. I-5.

2 Outlines of Classification and Special Morphology, p. 245.

E 2 


\section{Lang:-Prothalli of Ophioglossum pendulum}

eusporangiate Ferns. The antheridia might well be derived from a type like those of the existing Marattiaceae, the multiciliate spermatozoids constituting an additional point of resemblance. The archegonia are closely similar in development and structure in the two groups, in both of which a basal cell is constantly present. The embryogeny does not agree exactly, but the similarities are greater than between the Ophioglossaceae and the Lycopodiales. In the Marattiaceae no suspensor is present, and the apex of the stem and the primary leaf are derived from the epibasal half, but the primary root arises with the foot from the hypobasal half. This difference may find its explanation in the need for a large foot in a embryo attached to a deeply buried prothallus. At any rate an analogous disturbance of the primary members is evident when the species of Lycopodium with deeply buried prothalli are compared with those, the prothalli of which grow on or just beneath the surface.

To sum up the comparison with the Filicales, the form of the prothallus, structure of the sexual organs, and, though less clearly, the embryogeny of the Ophioglossaceae are such as might be expected in saprophytic forms derived from prothalli of the general type found in the Filicales. On the other hand, there appear to be no fundamental points of difference.

It was mentioned above that there is little to suggest the idea of any close relationship between the Ophioglossaceae and the Equisetales. The gametophyte of the latter has a general resemblance to that of the Filicales. It will be sufficient to say here that, while it seems quite possible that the Ophioglossaceous prothallus could have been derived from the Equisetaceous type, there is nothing to suggest such an origin as even equally probable to an origin from the Filicales.

From the above comparisons it would appear that the available evidence points to the origin of the type of prothallus found in the Ophioglossaceae from forms not unlike the gametophyte of the existing Marattiaceae, though possibly belonging to a more primitive group. It would further appear that little or nothing indicates an origin from the type of 
prothallus found in the homosporous Lycopodiales. This conclusion is essentially that at which Jeffrey ${ }^{1}$ arrived as a result of a similar comparison. When however it is borne in mind how little is known of the variation of the characters of the gametophyte under altered conditions, it is clear that this can only be regarded as a provisional view. The results of experimental cultures if critically interpreted might afford valuable additional evidence.

In the above discussion the characters of the sporophyte have been left out of account. If indications of sufficient weight-to render the origin of the Ophioglossaceae from a Filicineous stock improbable, and to connect them closely with the Lycopodiales-were afforded by the sporophyte, the value of characters of the gametophyte as indicating relationship between large groups would have to be reconsidered. Such evidence in the present case would require to be sufficiently clear to override the indications of a Filicineous affinity afforded by the prothallus. In the author's opinion such preponderating evidence has not been advanced, and it may indeed be questioned whether, in the case of this particular group, the characters retained by the gametophyte do not deserve to be given special weight.

${ }^{1}$ Loc. cit., p. 289. 


\title{
54 Lang.-Prothalli of Ophioglossum pendulum
}

\section{EXPLANATION OF FIGURES IN PLATES I, II, AND III.}

\begin{abstract}
Illustrating Dr. Lang's paper on the prothalli of Ophioglossum and Helminthostachys.
\end{abstract}

\section{PLATE I.}

Ophioglossum pendulum.

Fig. I. Young prothallus viewed from the side $(a)$, from above $(b)$, and from below $(c)$. ( $x$ 25.)

Fig. 2. Slightly older prothallus seated on a fragment of tissue in the humus. $\left(\begin{array}{l}x \\ 25\end{array}\right.$

Figs. 3, 4. Prothalli, showing the origin of the first branches. ( $x \quad 25$.

Figs. 5, 6. Mature prothalli seen from above; that shown in Fig. 6 is the largest found. $(\times 7$.

Fig. 7. Portion of a branch of one of the larger prothalli more highly magnified, showing the smooth apical cone, the unicellular hairs, and the antheridia. $(x 80$.

Figs. 8, 9. Young prothalli in longitudinal section. $(x$ 70. $)$

Fig. I0. Median longitudinal section of the apex of a branch, showing the segmentation of the initial cell. $(x .200$.

Fig. II. Transverse section of a similar apex. $(x 200$.

Fig. 12. Longitudinal section of a branch of the prothallus. ( $x$ 25.)

Fig. 13. Transverse section of a branch, passing through the region in which infection by the Fungus is taking place. ( $\times$ 70.)

Fig. I4. One of the unicellular hairs in vertical section. $(x$ 200.)

Fig. I5. Diagrammatic section of an old prothallus, passing through the organic centre and traversing two branches longitudinally; the regions inhabited by the endophyte are shaded. an. antheridia, ar. archegonia.

Fig. I6. Part of a transverse section of a branch, showing the entrance through a hair of an infecting hypha of the Fungus. ( $x$ 200.)

Fig. I7. Two cells of the prothallus containing the vesicular swellings of the Fungus. $n$. nucleus, $h$. hyphae, $v$. vesicles. $(\times 750$.

Figs. 18, 19, 20. Thiree stages of development of the antheridium represented in vertical section. $(\times 375$.

Fig. 2I. Vertical section of an almost mature antheridium from a transverse section of a branch. ( $\times 375$.)

Fig. 22. Tangential section through the outer wall of a mature antheridium, showing the triangular opercular cell. ( $\times 375$.)

Fig. 23. Vertical section of an opened antheridium from a longitudinal section of a branch. The shading indicates the tissue inhabited by the endophyte. $(x$ 200.) 
PLATE II.

Figs. 24-29. Ophioglossum pendulum.

Fig. 24. Vertical section of a young archegonium. ( $\times 375$.

Figs. 25,26 . Vertical sections of two nearly mature but unopened archegonia. $(\times 375$.

Fig. 27. Transverse section of the neck of an opened archegonium. $(x$ 375.)

Fig. 28. Prothallus bearing an embryo (em.). ( $\times 7$.

Fig. 29. Median longitudinal section of the embryo shown in the preceding figure. $(x$ 100.)

Figs. 30-49. Helminthostachys.

Figs. 30, 3I. Two of the smallest prothalli of Helminthostachys found. ( $\times$ 7.)

Figs. 32, 33, 34. Three male prothalli. ( $\times 7$.

Fig. 35. Prothallus bearing antheridia, and, nearer the apex, archegonia and an embryo. $(\times 7$.

Figs. 36,37 . Two female prothalli bearing embryos. ( $\times 7$.)

Figs. $38,39,40$. Diagrammatic median longitudinal sections of one of the smallest prothalli, of a male prothallus, and of a female prothallus respectively, showing the relative proportions borne to each other by the vegetative and sexual regions. $a$. apex, l.l. lobes of the vegetative region, $a n$. antheridia, $a r$. archegonia, $e$. embryo. (Fig. $38, \times 25$, the others $\times 7$. )

Fig. 4I. Median longitudinal section of the apex, showing the segmentation of the initial cell. $(x$ 200.)

Fig. 42. Longitudinal section through the sexual region of a male prothallus. $(\times 25$.

Fig. 43. Transverse section throngh the sexual region of a male prothallus. $(\times 50$.

Fig. 44. Similar transverse section through the unlobed vegetative region of the same prothallus. $(x$ 50.)

Fig. 45. Part of a longitudinal section of the vegetative region of a young prothallus, showing a young lobe. The shaded cells of the internal tissue contain the endophyte. ( $x$ I 00 .)

Fig. 46. A single rhizoid containing a fungal hypha. ( $x$ 200.)

Fig. 47. Two rhizoids containing hyphae; the tips of the rhizoids have broken down. $(x$ 200. $)$

Fig. 48. The internal tissue of a young prothallus, showing the Fungus bearing numerous vesicles; the intervening cells contain starch. ( $x$ 375.)

Fig. 49. Corresponding tissue from a slightly older prothallus; the Fungus is shrivelled and dead, while the cells of the prothallus are packed with starch. $(x 375$.)

\section{PLATE III.}

\section{Helminthostachys,}

Figs. 50, 5I, 52. Vertical sections of young antheridia. ( $\times$ 200.)

Fig. 53. Transverse sections through a young antheridium about the same age as that in Fig. $5^{2} ; a$. through the wall; $b$. through the mass of spermatocytes. $(x$ 200.) 
Fig. 54. Vertical section through an almost mature antheridium, showing one dehiscence-cell in the wall. ( $x$ 200.)

Fig. 55. Surface-view of the outer wall of an opened antheridium, showing two dehiscence-cells, one of which has broken down. ( $x$ 200.)

Fig. 56. Vertical section of two antheridia, the wall of one of which shows two dehiscence-cells. ( $x$ I IO.)

Fig. 57. Vertical section of an unopened archegonium. $(x$ 200.)

Fig. 58. Cross section of an archegonium neck. ( $\times 200$.

Fig. 59. Median section of the embryo borne on the prothallus shown in Fig. 35. $f$. foot, $r$. primary root, $l$. first leaf, st. apex of stem. $\left(\times 5_{50}\right.$.)

Fig. 6o. Apical region of the stem of the embryo in the preceding figure, showing the form and segmentation of the initial cell. $h$. hairs in the apical depression, l.t. first leaf-trace. $(\times 250$. $)$

Fig. 6I. Young plant attached to the prothallus. (Nat. size.)

Fig. 62. An older plant attached to the prothallus. (Nat. size.)

Fig. 63. Transverse section of the second root of a young plant, showing the position of the mycorhizal fungus. $\left(x 5^{\circ}\right.$.)

- Fig. 64. Transverse section of the stele of the primary root. ( $x$ I I 0. )

Fig. 65 . Transverse section of the stele of the stem below the origin of the first leaf. ( $x$ I I 10. )

Fig. 66. One half of a transverse section of this stele more highly magnified. $e n$. endodermis, $p c$. pericycle, $p h l$. phloem, $x$. xylem, $p$. pith. $(\times 330$.)

Fig. 67. Transverse section of the stele represented in Fig. 65 , showing the origin of the first leaf-trace. ( $X$ I IO.)

Fig. 68. Similar section of another stele, showing the origin of a leaf-trace with centripetal tracheides. ( $X$ II IO.)

Fig. 69. Transverse section of the two vascular bundles at the base of a leaf. i.sp. adaxial intercellular space. ( $x$ II 0 .)

Fig. 70. Transverse section of the stele of a young plant near to the apex, showing the first developed tracheides around the pith. ( $X$ II IO.) 
Arnats of Botany.
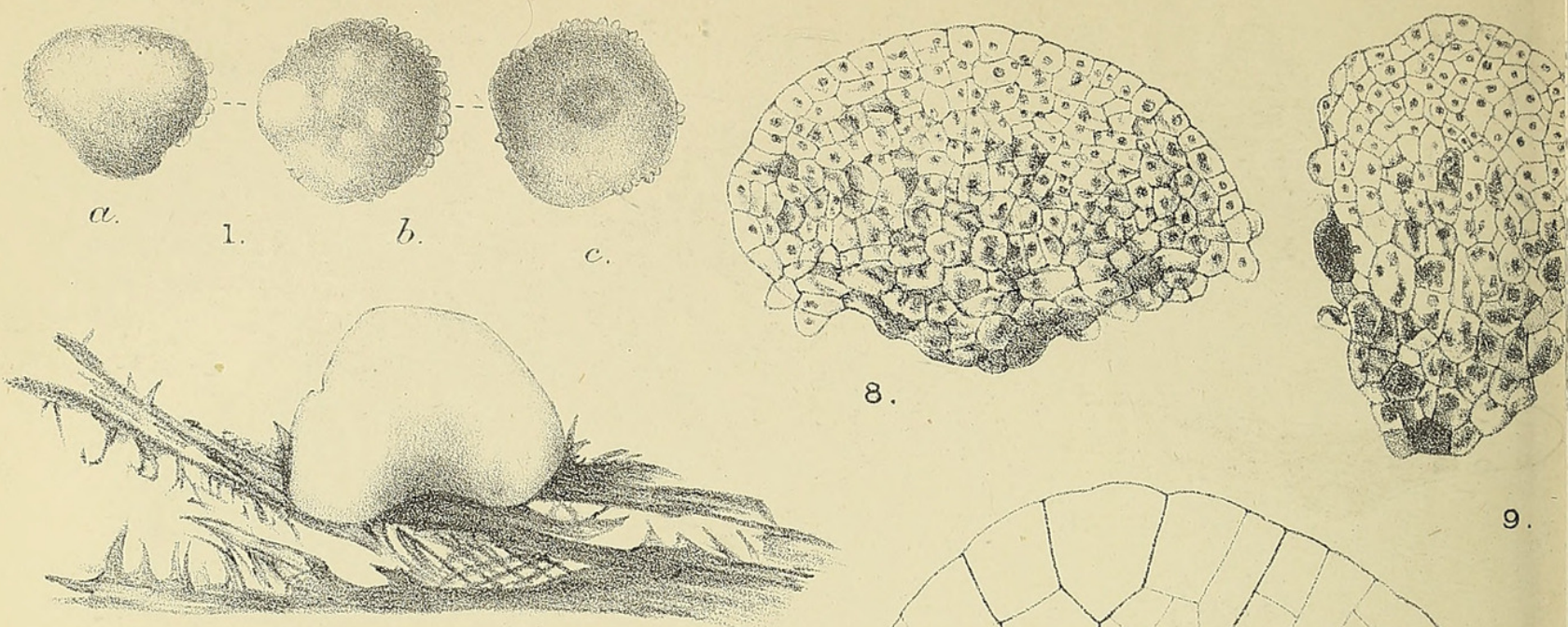

8.

2

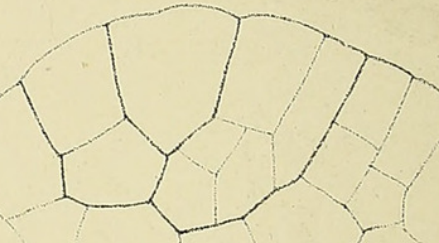

9.
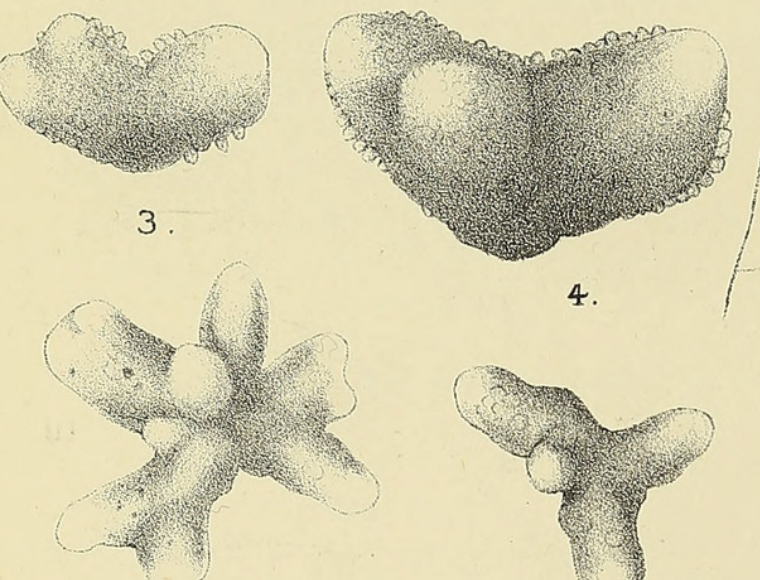

6

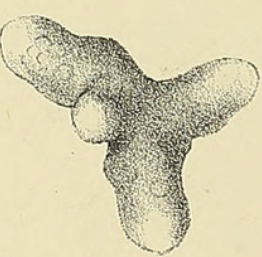

5
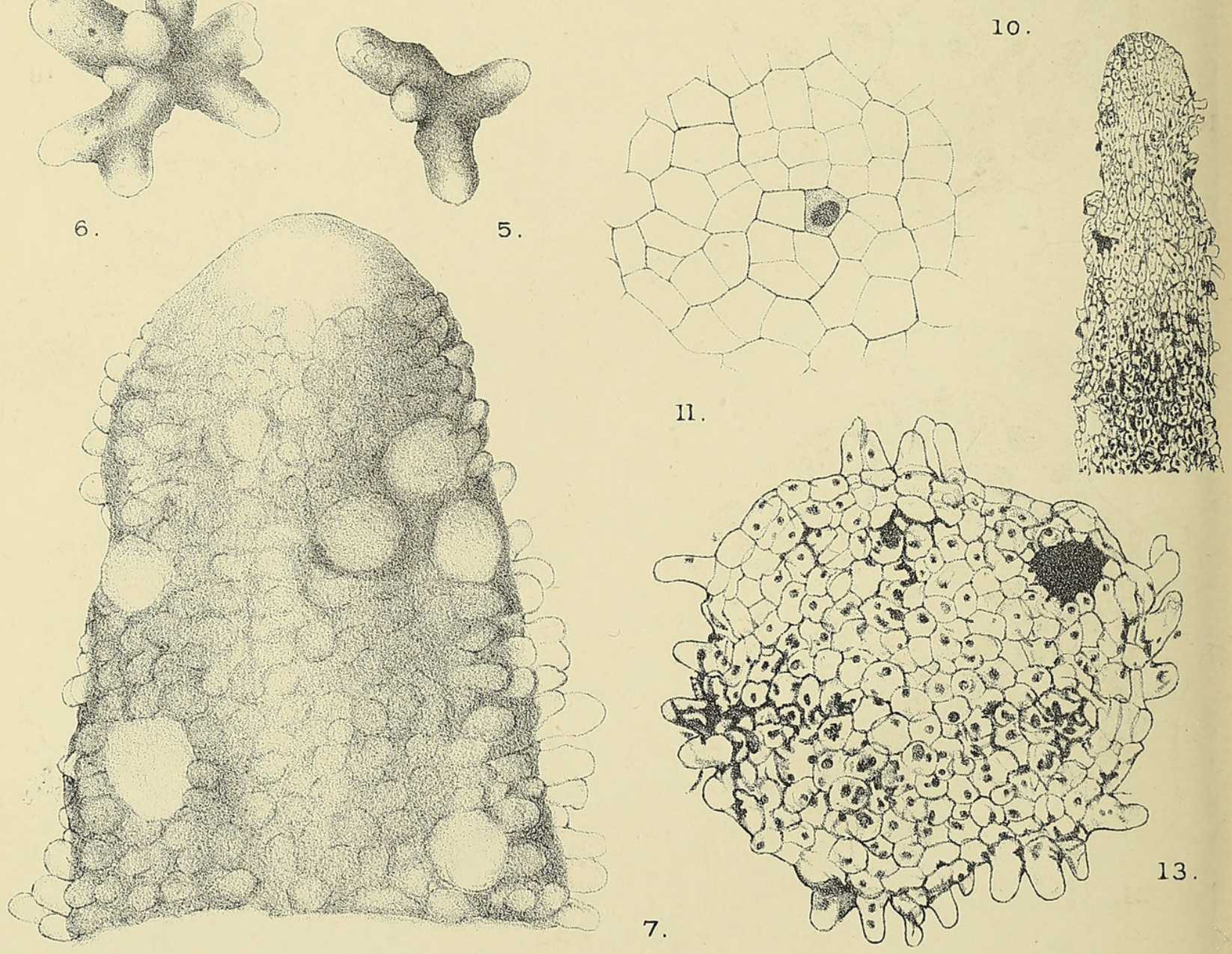

W. H.L. del.

LANG.- OPHIOGLOSSUM PENDULUM. 
Vol.XVI, PI.I.

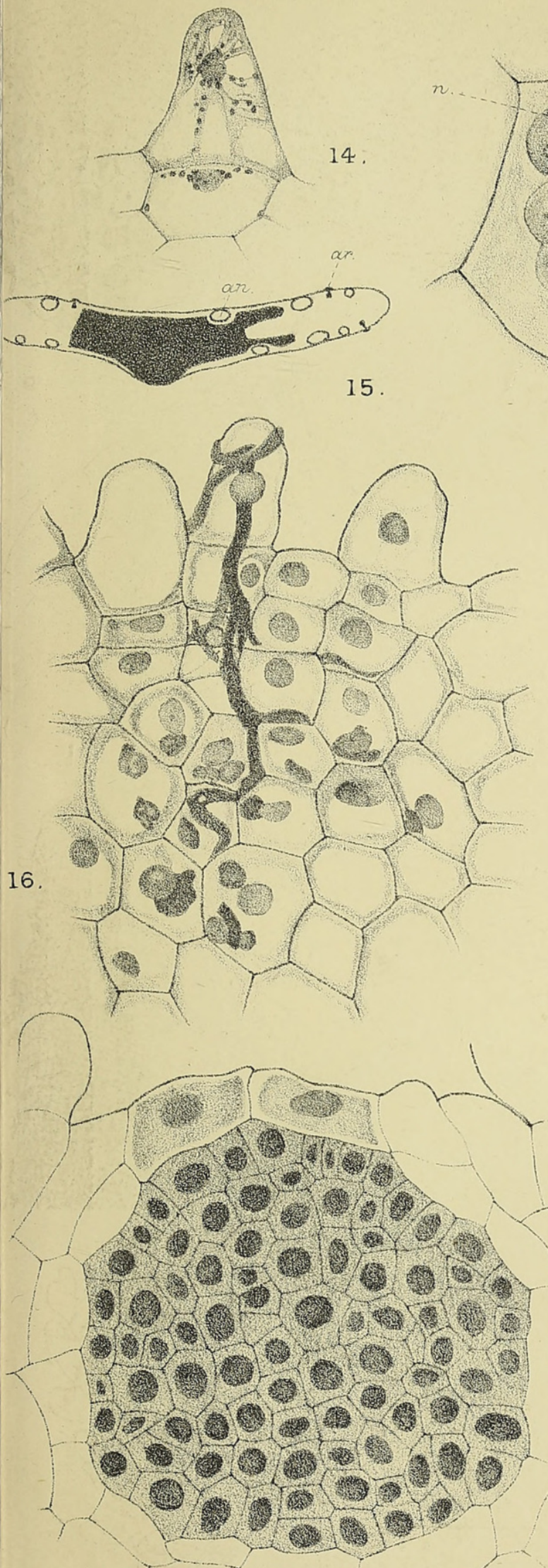

21.
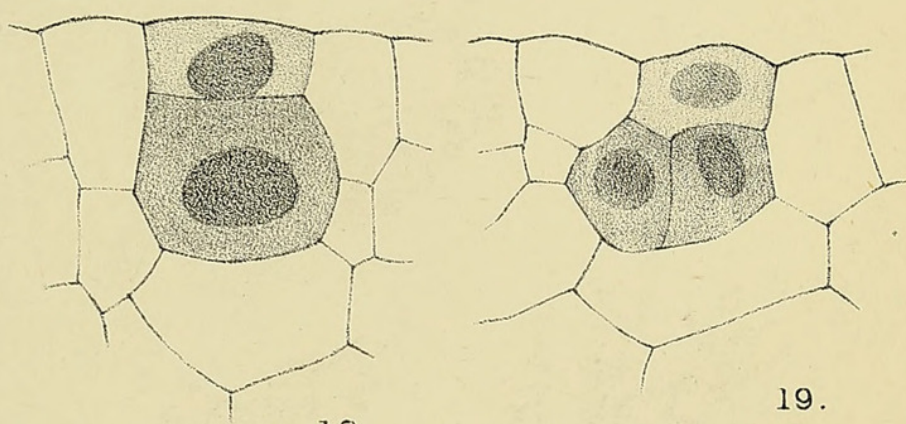

18.

17.

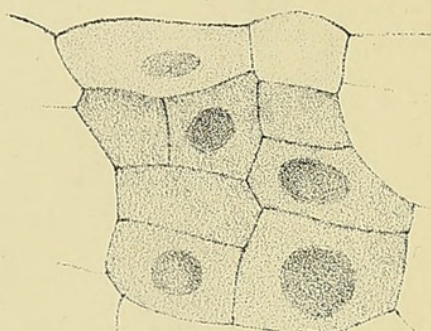

22.

20.

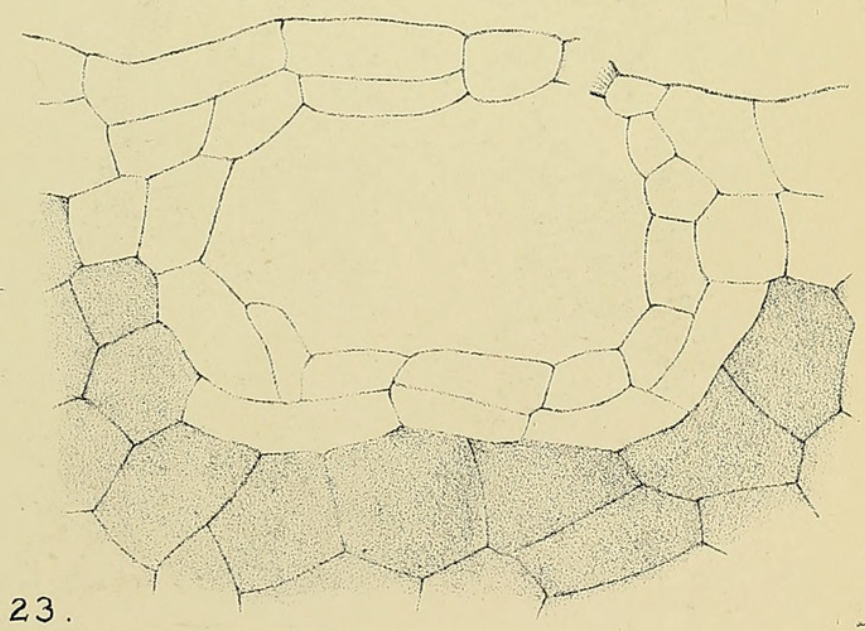

University Press, Oxford. 

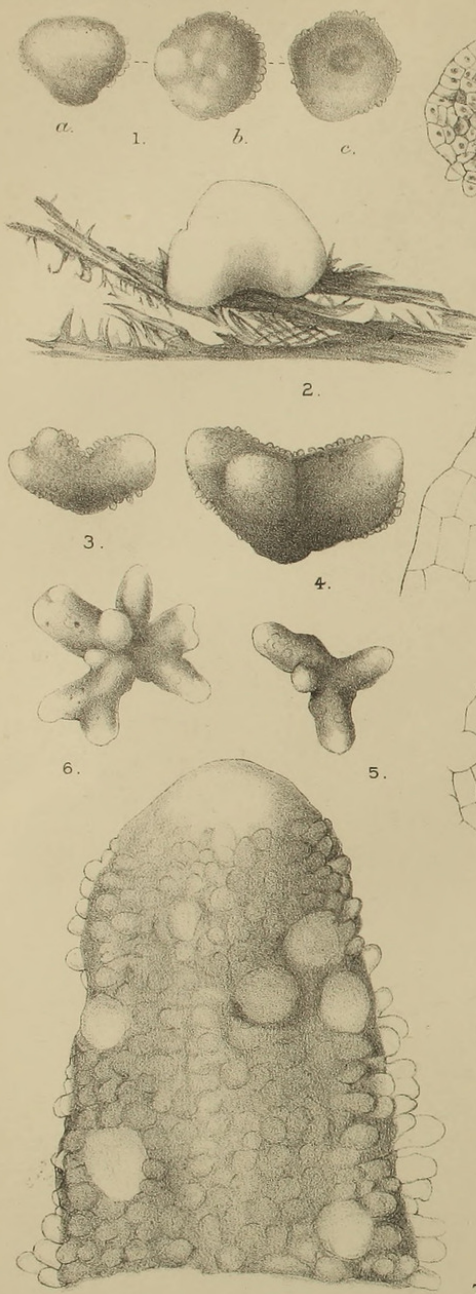
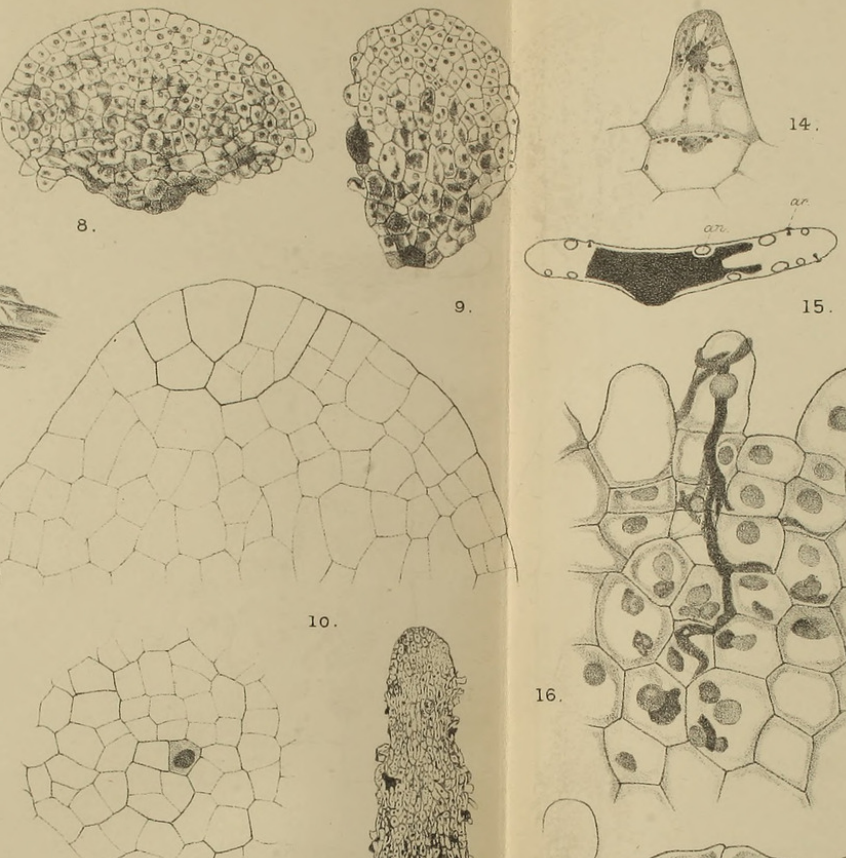

10
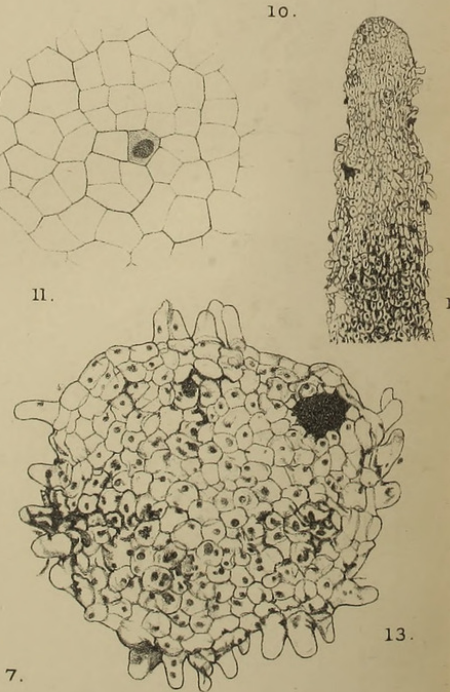

LANG.- OPHIOGLOSSUM PENDULUM.
16.
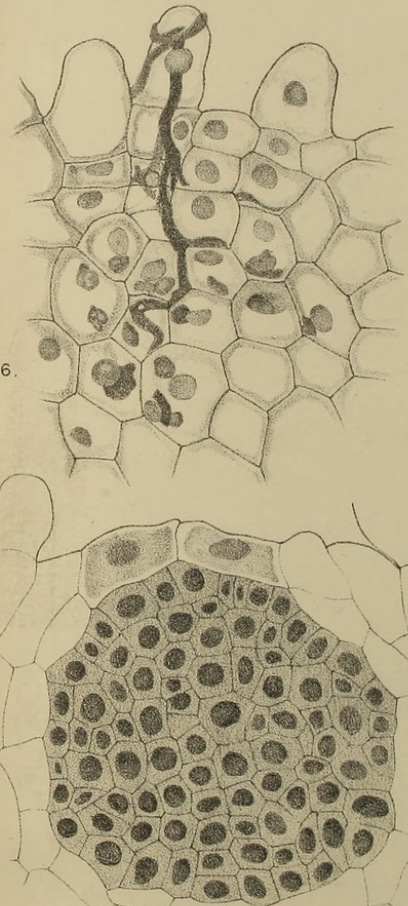

21
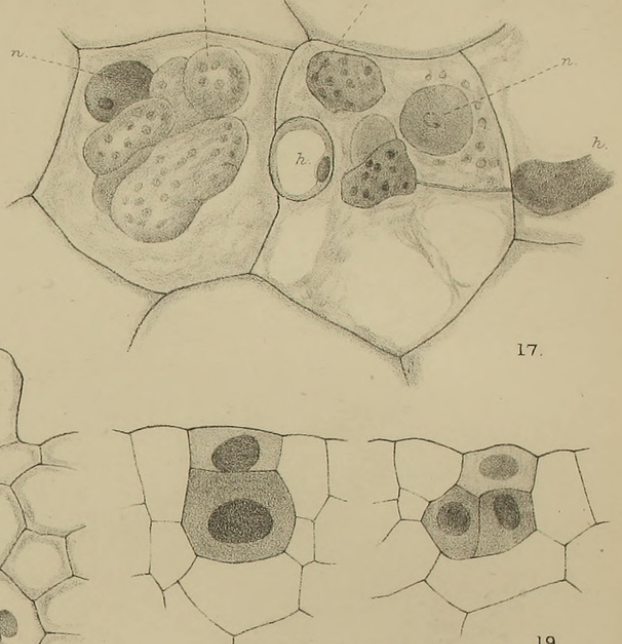

19.
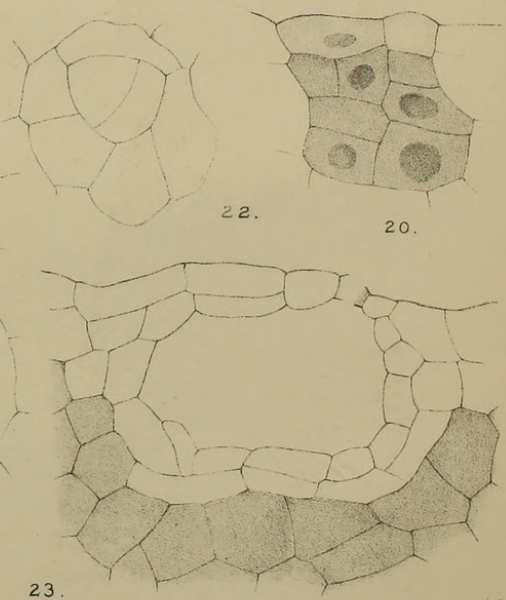

University Prass, Oxiord 


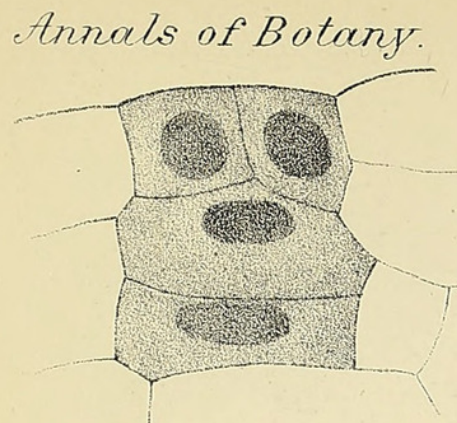

24
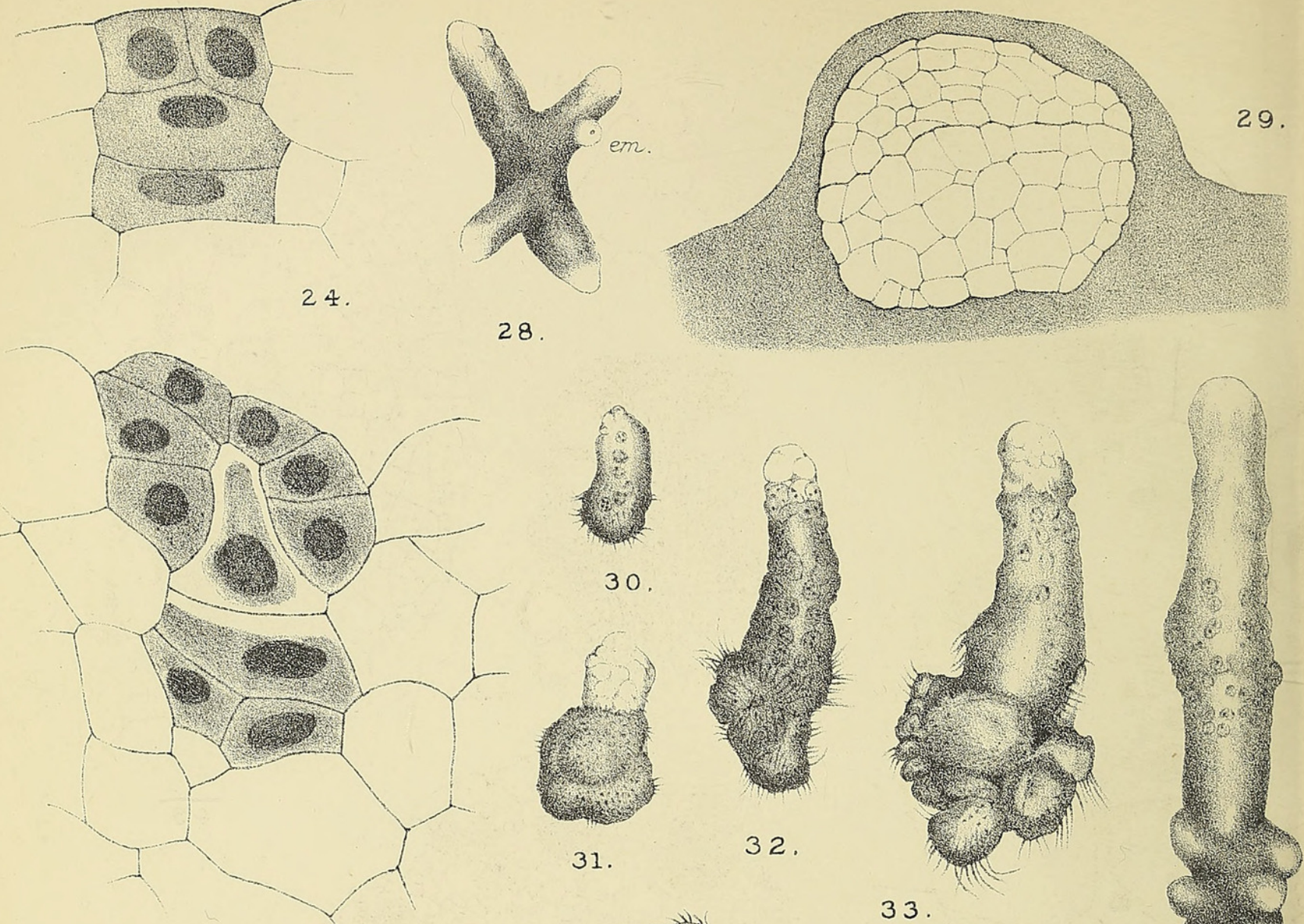

28.
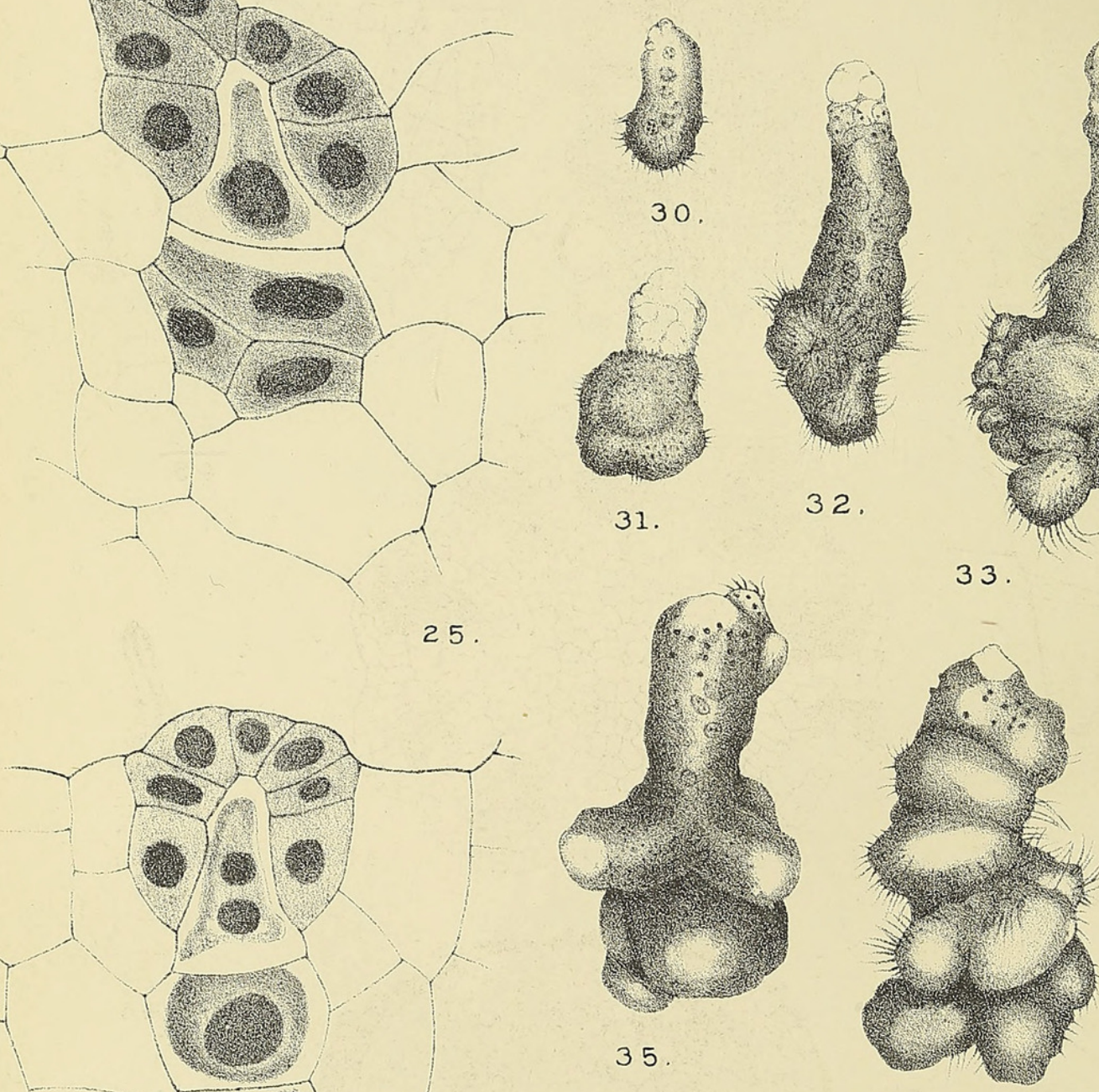

34.
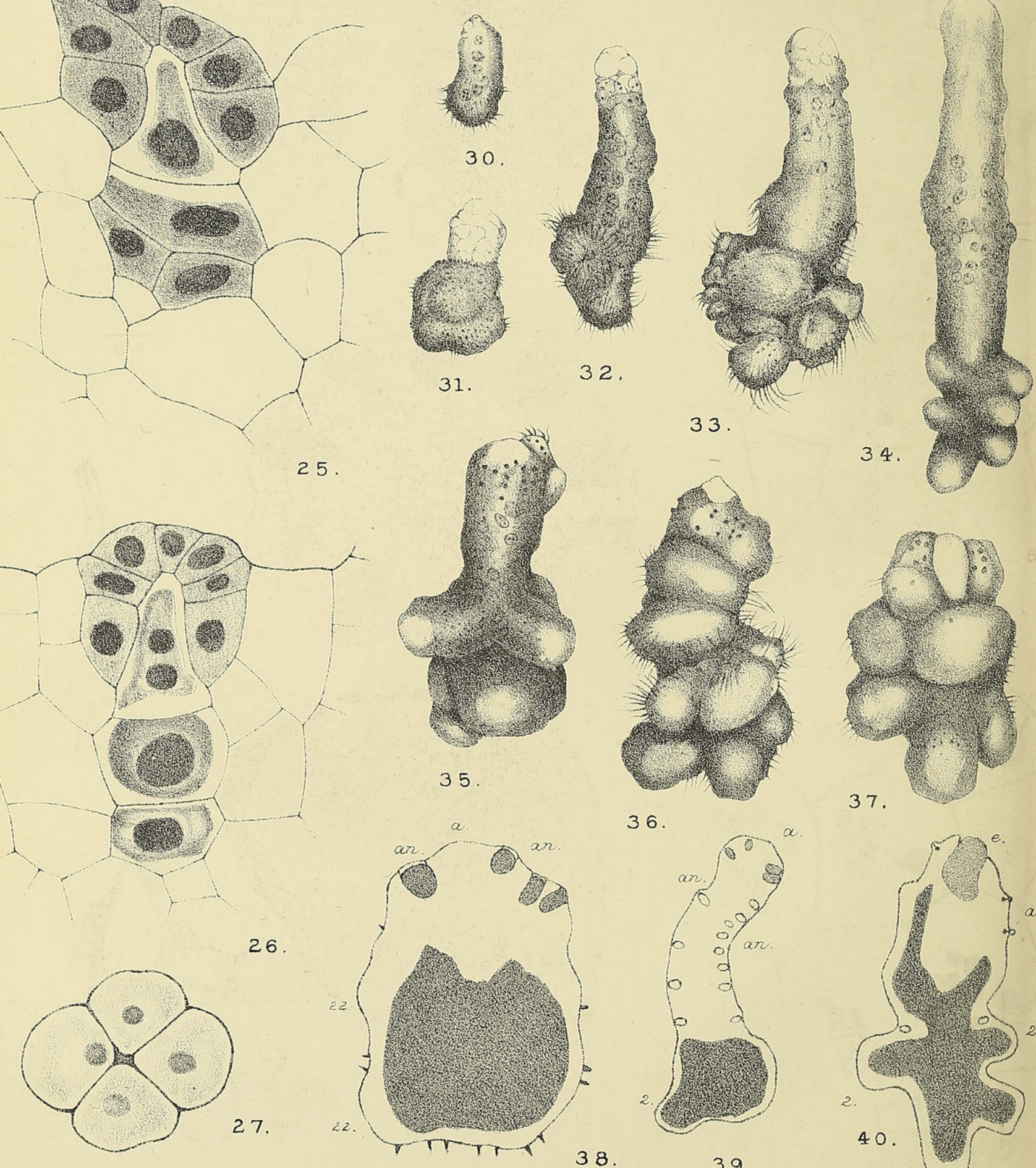

36.
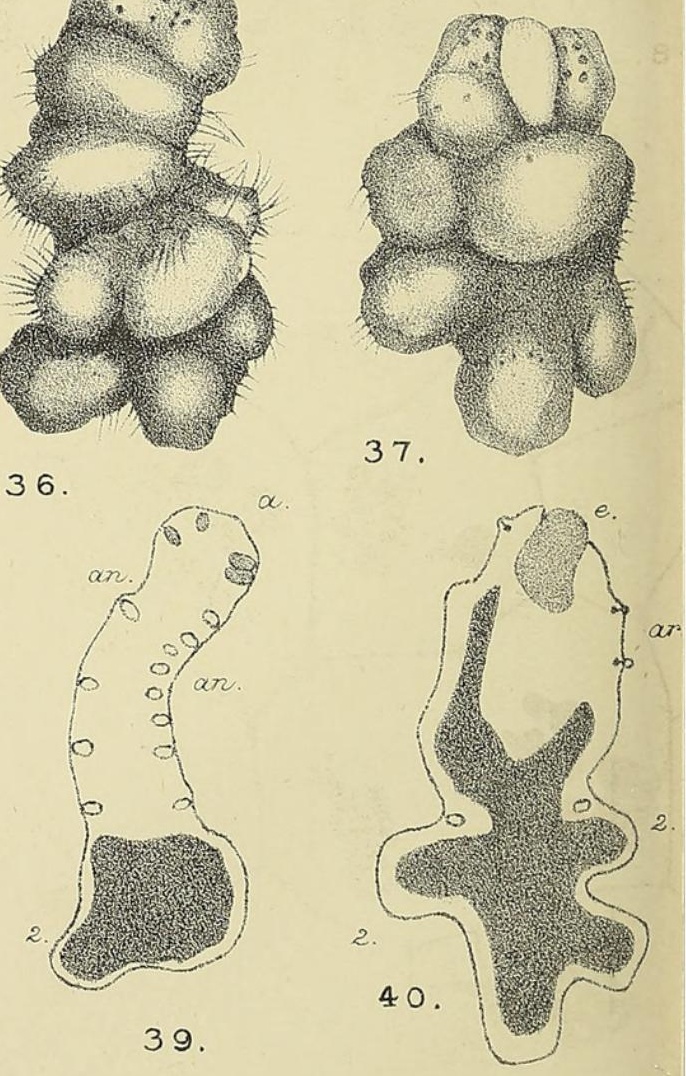

W. H. L. del.

LANG.- OPHIOGLOSSUM PENDULUM Figs. 24-29. HELMINTHOSTACHYS Figs.30-49. 


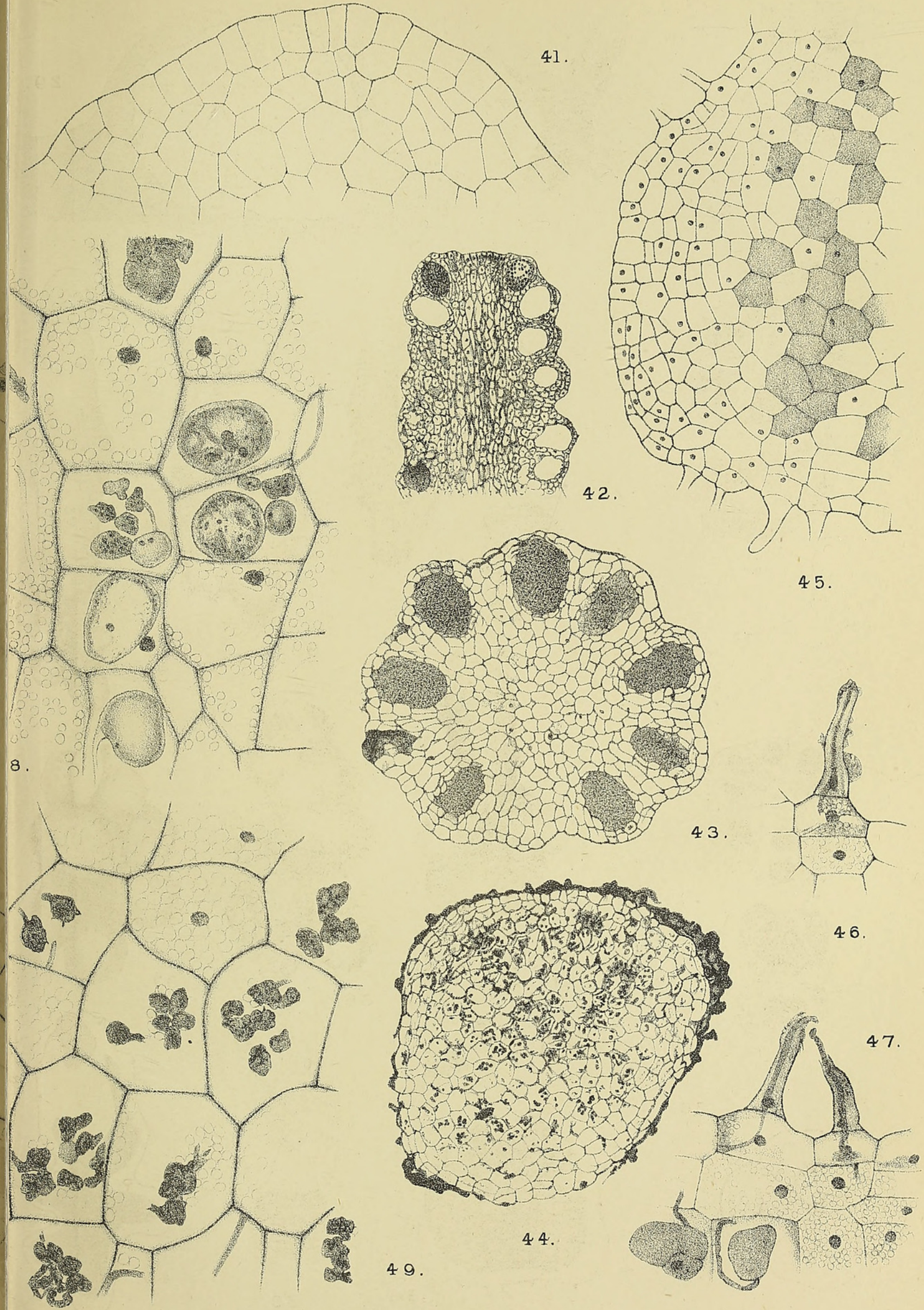



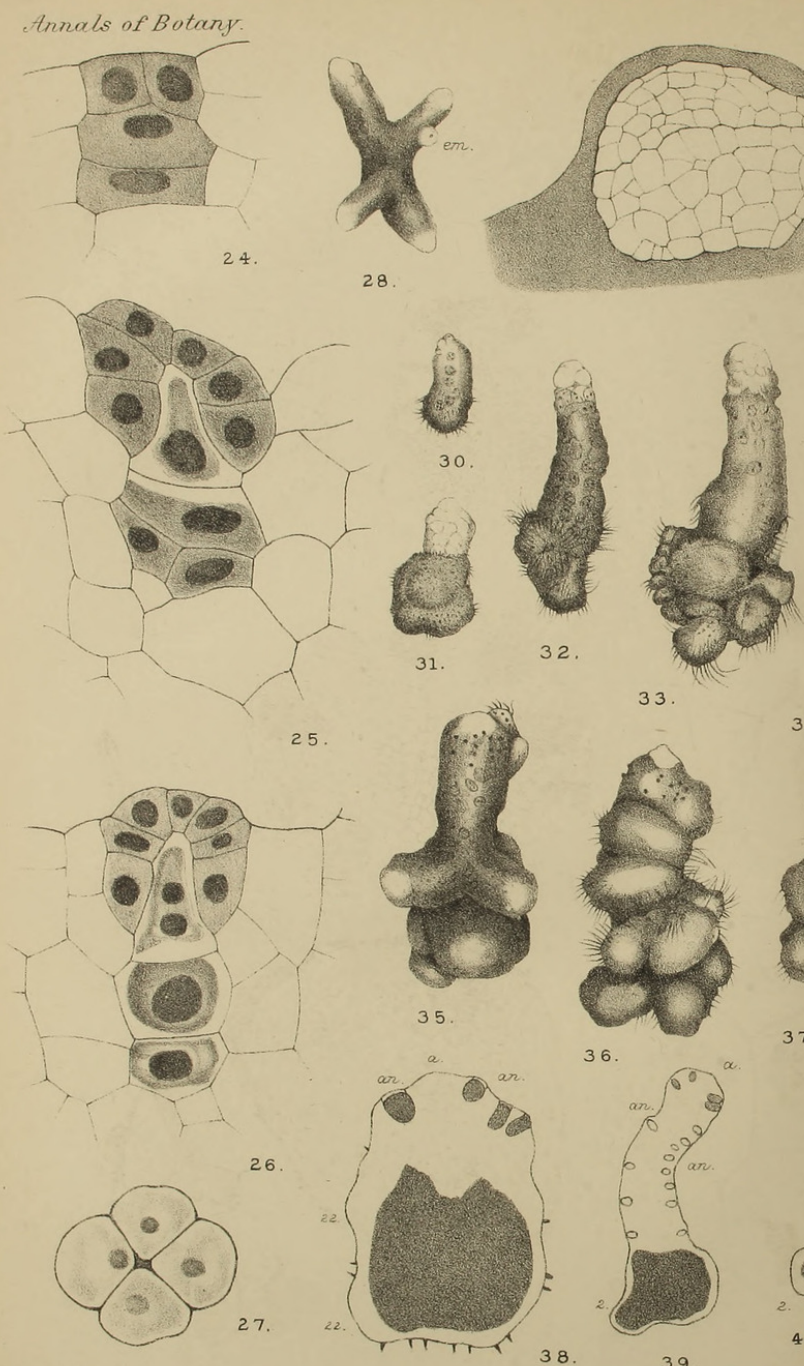

38.
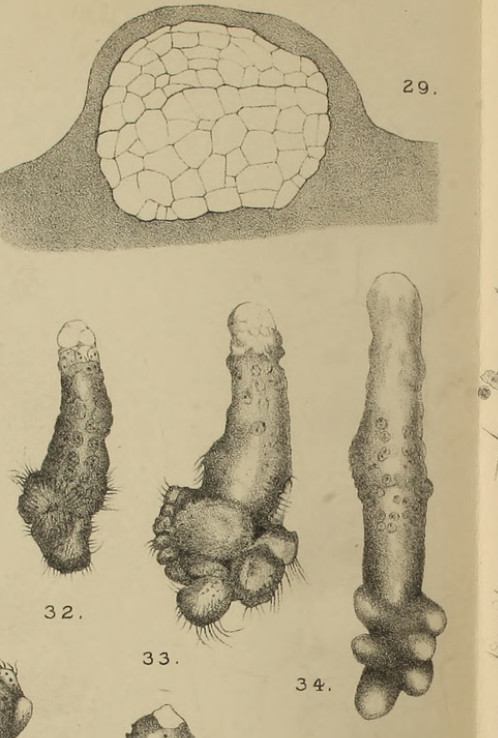

Vol. XTI PL.IL.
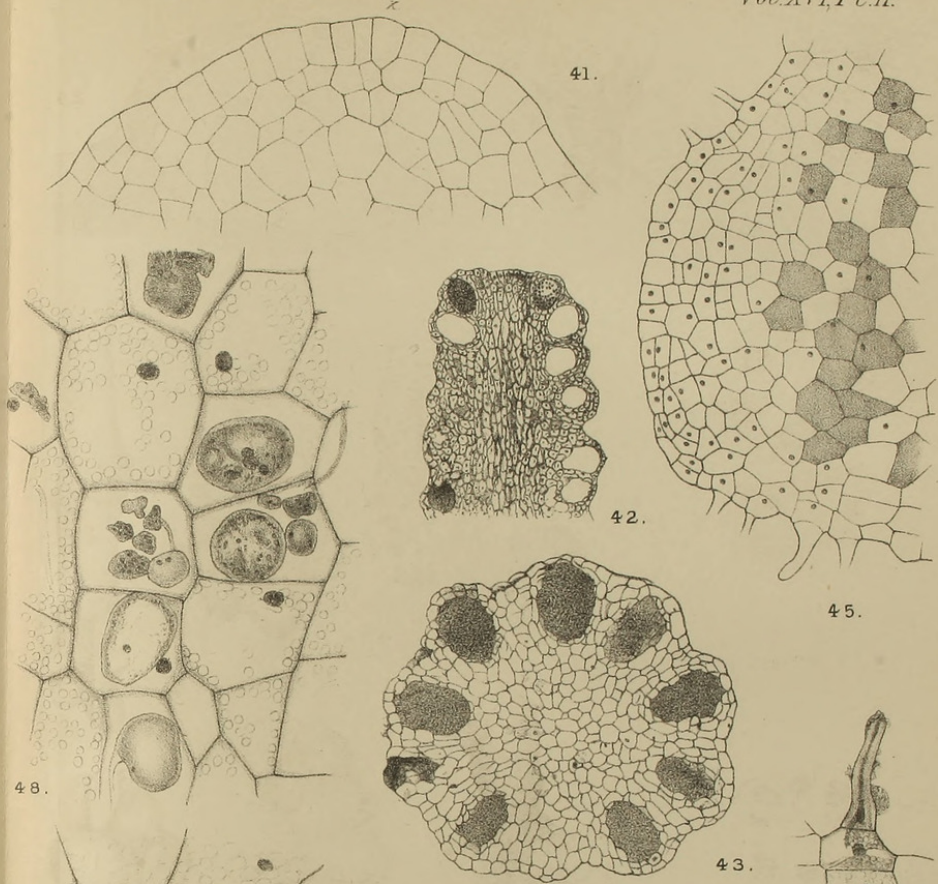

45.
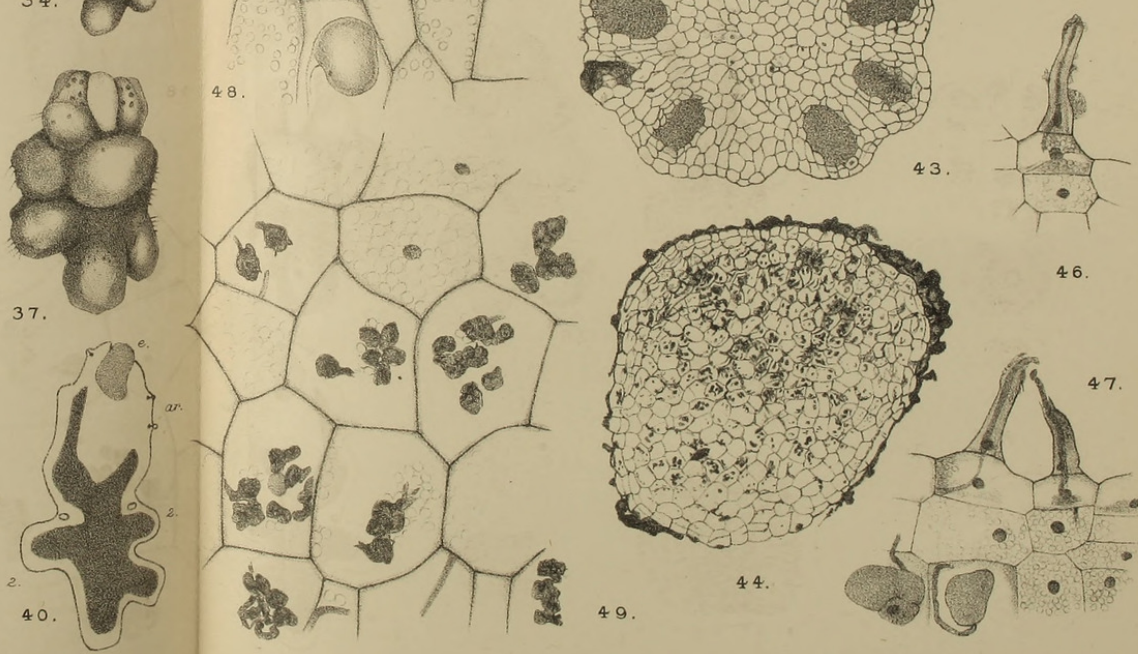

LANG.- OPHIOGLOSSUM PENDULUM Figs. 24-29 

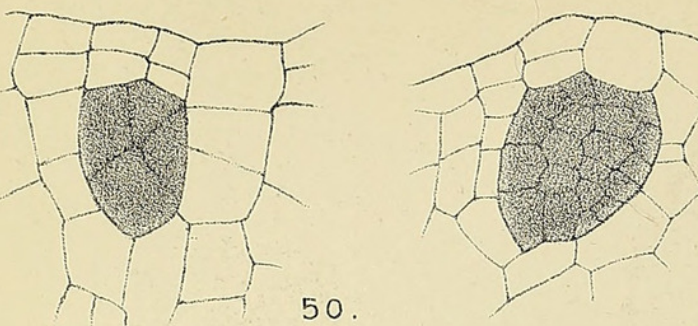

51

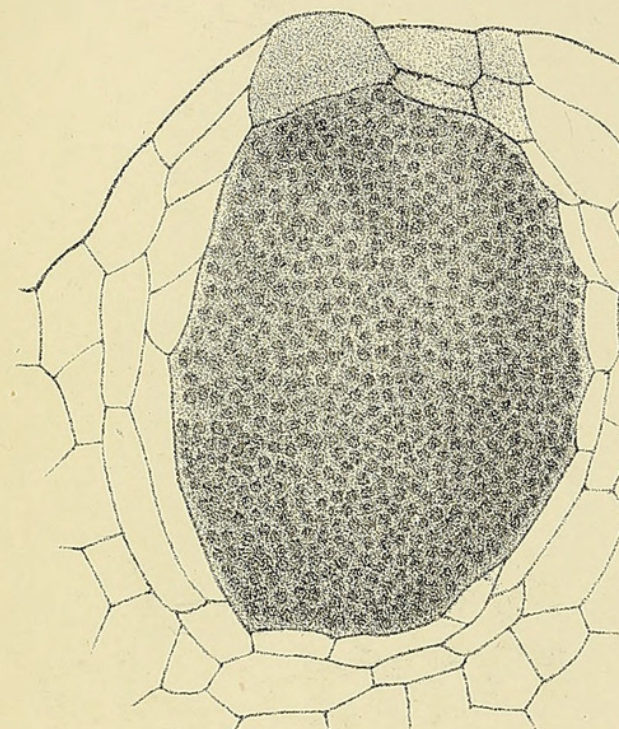

54
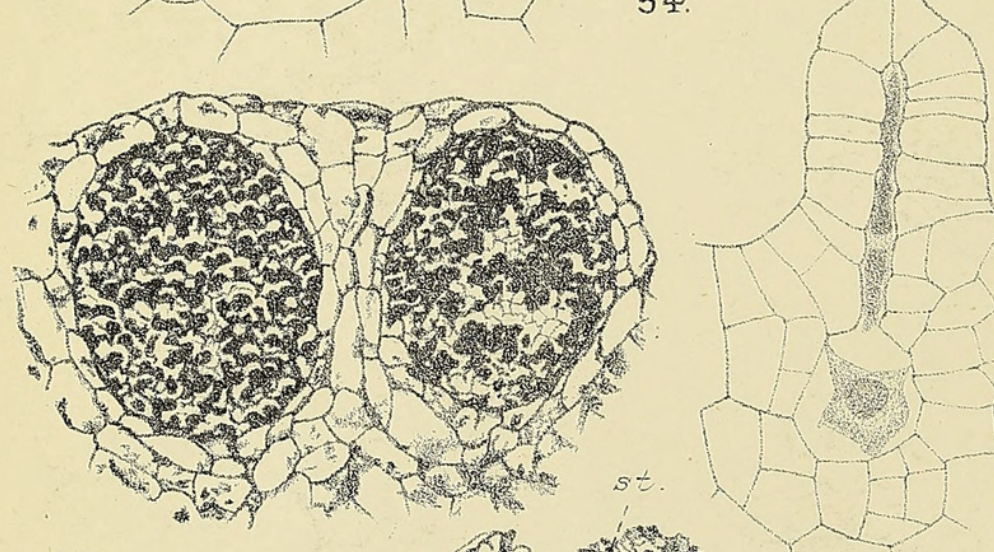

56

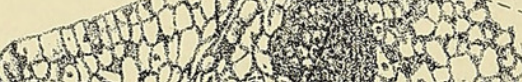

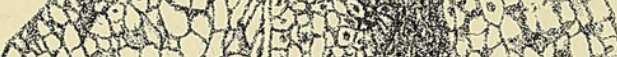

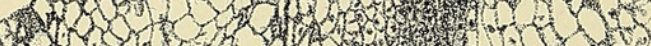
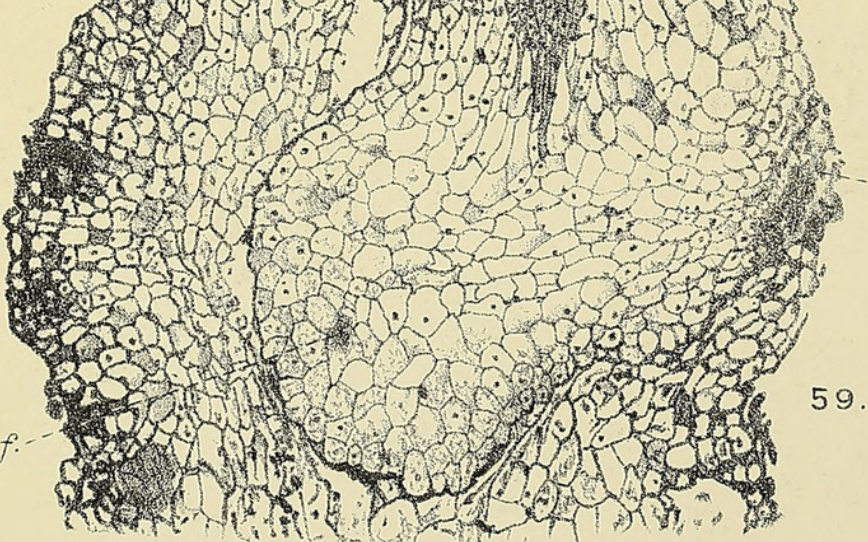

W.H.L. del.
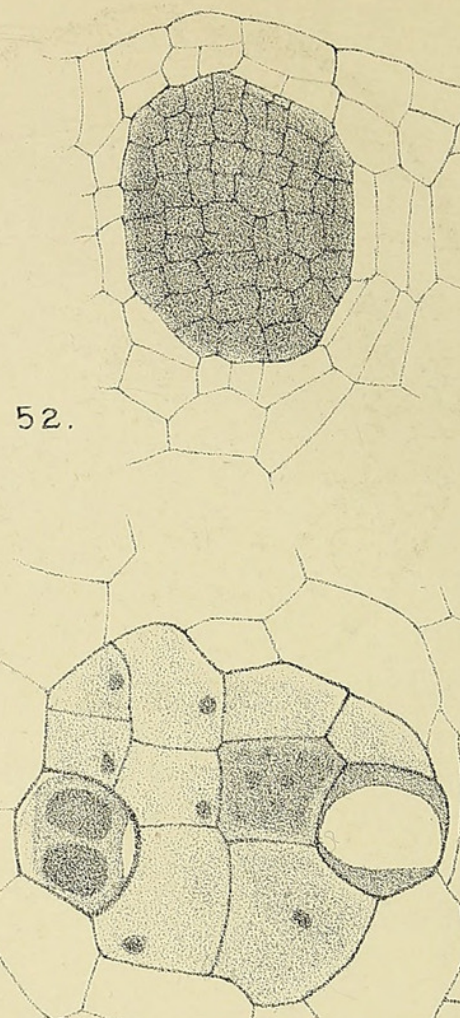

52

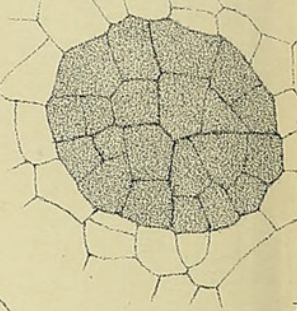

55

61.

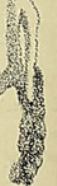

58

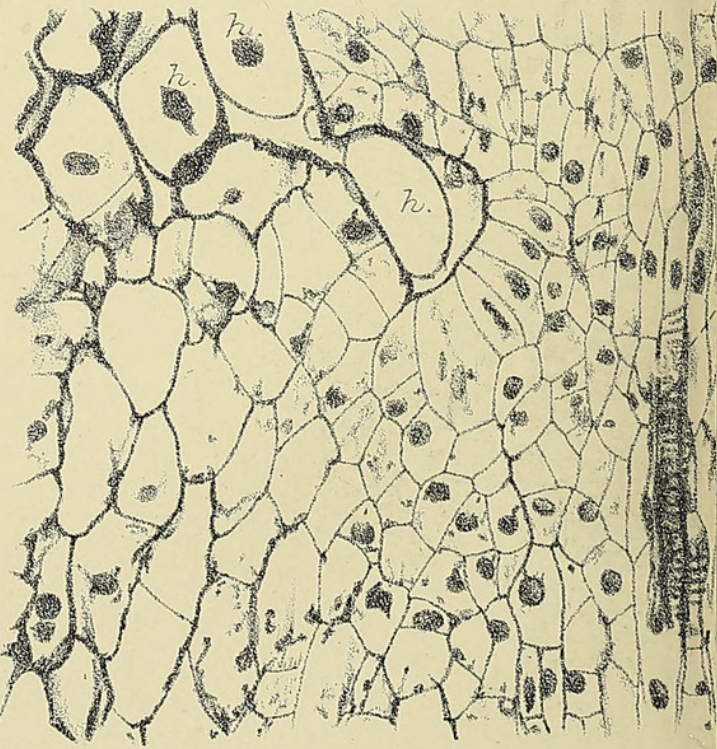

LANG.- HELMINTHOSTACHYS 

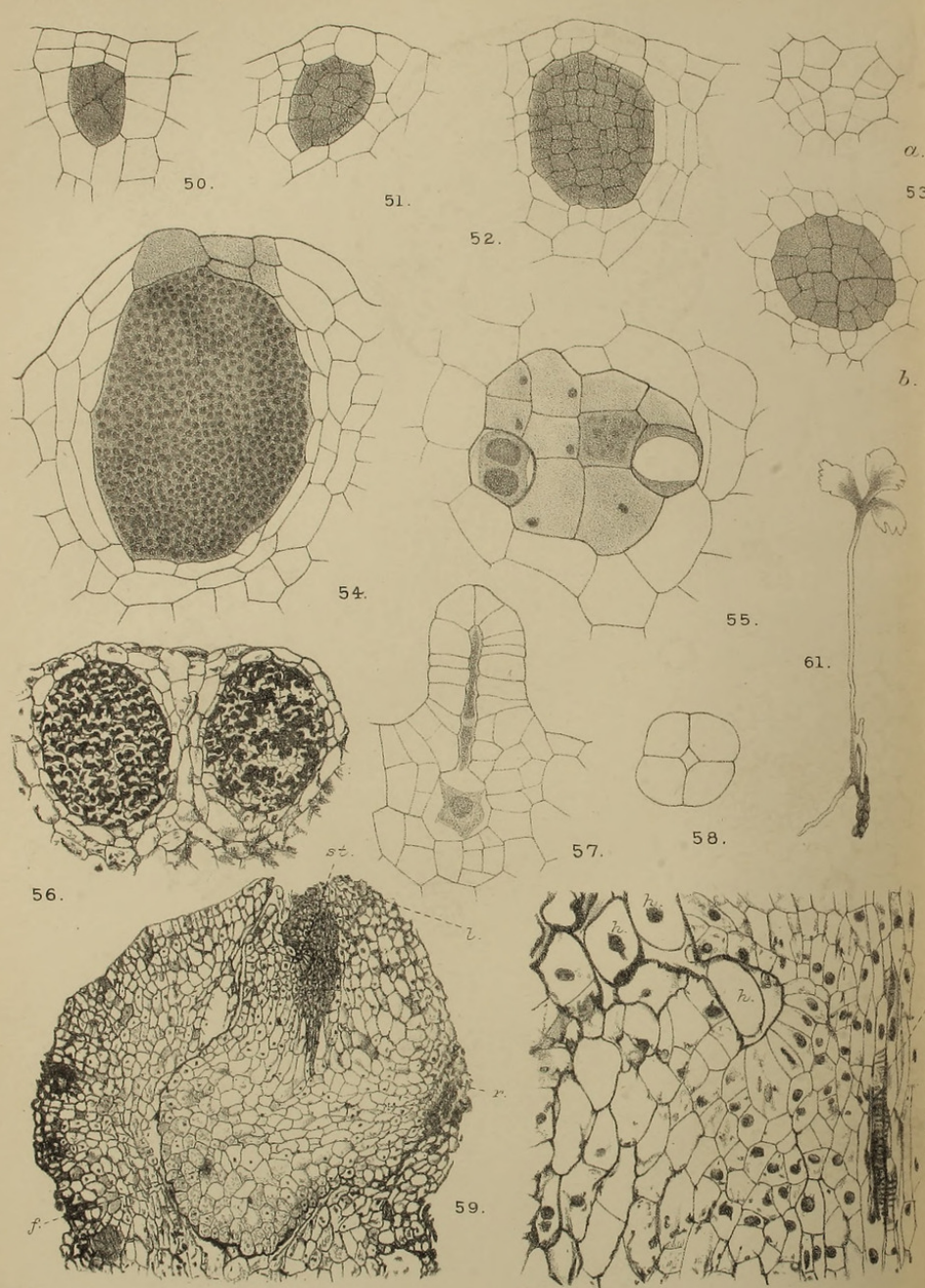
W.H.L. del.
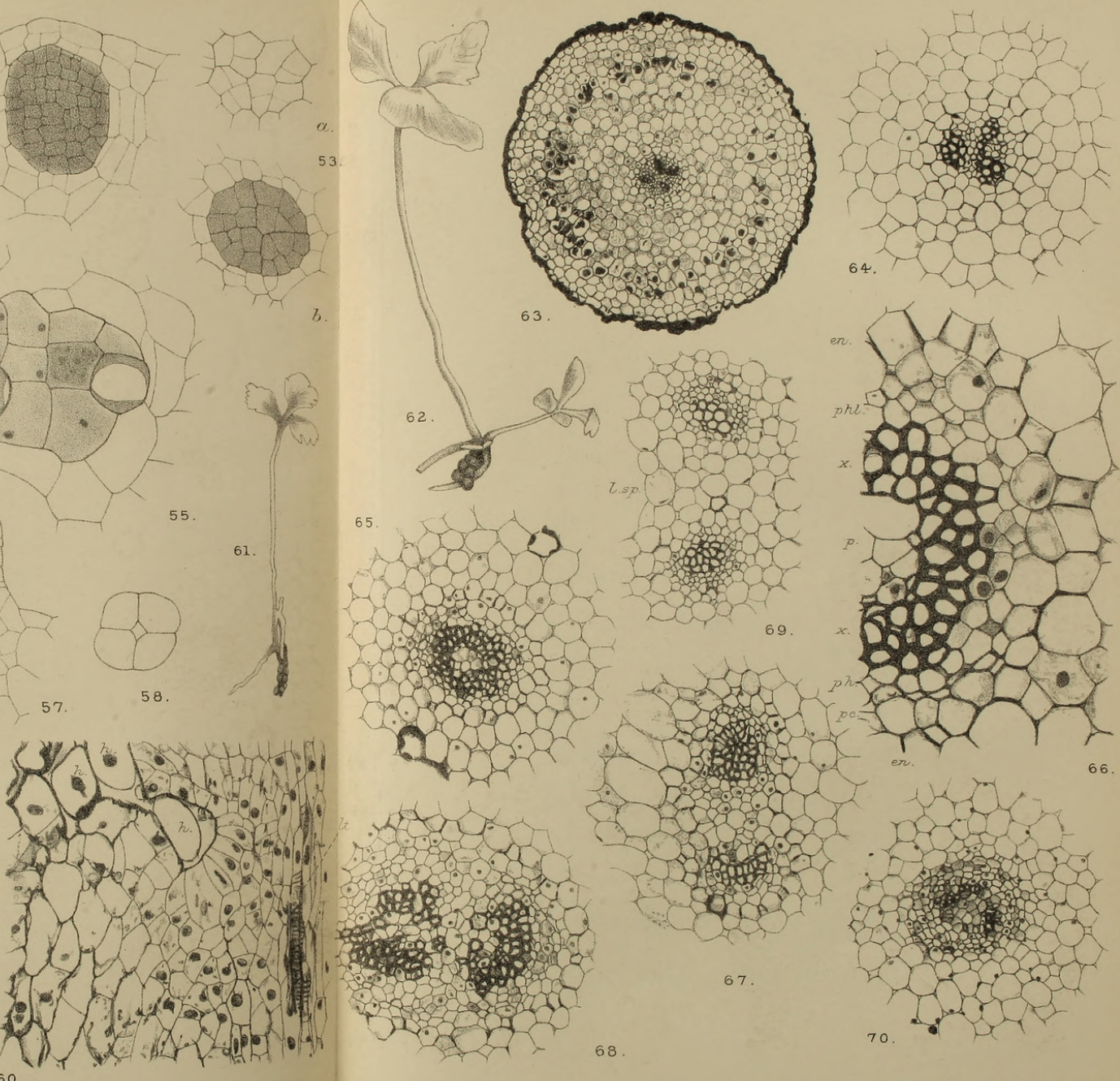

University Press, 0 xford. 


\section{$2 \mathrm{BHL}$ Biodiversity Heritage Library}

Lang, W. H. 1902. "On the prothalli of Ophioglossum pendulum and Helminthostachys zeylanica." Annals of botany 16, 23-56.

https://doi.org/10.1093/oxfordjournals.aob.a088870.

View This Item Online: https://www.biodiversitylibrary.org/item/233980

DOI: https://doi.org/10.1093/oxfordjournals.aob.a088870

Permalink: https://www.biodiversitylibrary.org/partpdf/318662

\section{Holding Institution}

Smithsonian Libraries

\section{Sponsored by}

Biodiversity Heritage Library

\section{Copyright \& Reuse}

Copyright Status: Not in copyright. The BHL knows of no copyright restrictions on this item.

This document was created from content at the Biodiversity Heritage Library, the world's largest open access digital library for biodiversity literature and archives. Visit BHL at https://www.biodiversitylibrary.org. 